Mariz Vainzof

\title{
ESTUDOS MOLECULARES E PROTÉICOS NAS MIOPATIAS CONGÊNITAS E DISTROFIAS MUSCULARES PROGRESSIVAS
}

Tese apresentada ao Instituto de Biociências da Universiadade de São Paulo (Departamento de Genética e Biologia Evolutiva), para a obtenção do título de Professor Livre-Docente.

Laboratório de Proteínas Musculares e Histopatologia Comparada Centro de Estudos do Genoma Humano

São Paulo

2006 
FICHA CATALOGRÁFICA

Vainzof, M

Estudos Moleculares e Protéicos nas miopatias congênitas e Distrofias Musculares Progressivas. / Mariz Vainzof - São Paulo, 2006.

Tese (Livre-Docência) - Instituto de Biociências da Universidade de São Paulo. Departamento de Genética e Biologia Evolutiva, Centro de Estudos do Genoma Humano.

Palavras chave: distrofias musculares progressivas, miopatias congênitas, distrofia muscular congênita, proteínas musculares, músculo miopático

USP/IB/ 


\section{AGRADECIMENTOS}

O presente trabalho somente foi possível graças à ajuda e contribuição de um número gigantesco de pessoas, tanto no âmbito profissional, como pessoal. Como será impossível nomear a todos, gostaria muito que aceitem em conjunto o meu imenso

\section{MUITO OBRIGADA}

Aos pacientes que tanto contribuíram direta e indiretamente com este estudo, e cuja fê e torcida, servem de estímulo e direcionamento para as pesquisas realizadas.

À Profa. Dra. Mayana Zatz, por ter me introduzido no estudo das doenças neuromusculares, e por todos estes anos de colaboração e trabalho em conjunto.

À Profa. Dra. Maria Rita Passos Bueno, por nossas discussões, troca de idéias e aprendizado constante. Como eram bons os velhos tempos de nosso trabalho complementar juntas....

À minha queridíssima Marta Canovas, minha "alma gêmea", por todos estes anos de trabalho laboratorial em conjunto. Suas mãos de fada possibilitaram a publicação de pranchas imunohistoquímicas respeitadas internacionalmente.

À super querida e unânime Dra. Lydia U. Yamamoto, que nos últimos 8 anos, com sua calma e ponderação, tanto me ajudou no dia a dia, na troca de idéias, na formação do grupo, implantação de novas metodologias e na organização do congresso da WMS no Brasil...

Aos meus muito queridos alunos e colaboradores, passados e atuais, que tanto me ajudaram a construir esta linha de pesquisas: Cleber da Silva Costa, Viviane Palhares Muniz, Juliana Gurgel-Giannetti, Telma L.F.Gouveia, Patrícia Mayumi Kossugue, Bruno Lazzari de Lima, Danielle Ayub de Barros, Paula Cristina Gogueira Onofre, Poliana Cristina de Melo Martins, Sheila Cherchat., Fernando Janczur Velloso, Luciana Luchesi Quintanilha Fogaça, Giselle Izzo, Dinorah Zilberztajn, Vanessa Ferreira Lopes, Helena P. Lima, Áurea Beatriz Martins, Karen Sell, Lucas de Sant'Anna Maia. E aos muitos outros que vieram, aprenderam, aplicaram e também ensinaram...

A Eloísa de Sá Moreira e Alessandra Starling, pela amizade, e trabalho conjunto muito produtivo.

A todos os pesquisadores internacionais que me enviaram os seus preciosos anticorpos, possibilitando os estudos colaborativos aprentados nesta tese.

Aos Diversos Centros de Patologia Muscular, que encaminharam suas biopsias musculares para complementação dos estudos.

À professora Célia Koiffman, pelo apoio constante, amizade, e por me trazer de volta ao chão, em momentos de crise... fáceis!).

À prof. Dra. Anita Vajntal, pela amizade incondicional e apoio nos momentos difíceis (e também nos

Ao prof. Dr. Paulo A. Otto, atual chefe do departamento de Genética e Biologia Evolutiva, e alem de colega e amigo sempre pronto a ajudar nas avaliações estatísticas.

À Dra. Rita de Cássia Pavanello e Ivo Pavanello Filho, pela ajuda nos diagnósticos e na realização das biopsias musculares e pela amizade.

Ao Prof. Dr. Fernando Kok, que alem de ser um excelente amigo, ajuda com o seu conhecimento enciclopédico na elucidação diagnóstica dos casos difíceis.

À Dra. Helga C. Silva, e Dra. Ana Maria Tsanaclis, pela colaboração de longa data na analise anatomopatologica das biopsias musculares, e nos estudos da Hipertermia Maligna. 
Ao Prof. Dr. Antonio Levy, que desde o inicio, abriu o seu ambulatório e disponibilizou suas biopsias musculares para os nossos estudos.

Ao Prof. Dr. Acary S.B. Oliveira e equipe do setor Neuromuscular da UNIFESP, por ser um colaborador e apoiador constante do nosso trabalho.

À Dra. Juliana Gurgel-Gianneti, que ajudou a implantar os estudos nos pacientes com miopatias nemalinicas, e se empenhou tanto para fazer do meu primeiro aluno de doutorado, um sucesso!!

Ä Dra. Julia Paim, da Rede Sarah Kubishcek de Belo Horizonte, pela excelente colaboração e ampliação dos horizontes.

Aos colegas e funcionários do Centro de Estudos do Genoma Humano, pela convivência harmoniosa, ajuda e suporte no dia a dia. Em especial, ao Miguel, Lucas, Sr. Walter e Mariazinha, por estarem sempre disponíveis para ajudar... e agüentar as pressões e emergências diárias...

Aos colegas e amigos do departamento de Genética e Biologia Evolutiva, e em especial para a Neide e Constancia, pela ajuda nos aspectos burocráticos.

Equipe de profissionais da ABDIM, atuais e passados, que tanto ajudaram na avaliação dos pacientes e seu seguimento.

Ao Dr. Luis Netto, pela imensa ajuda e colaboração para a expressão de proteínas "in vitro".

Às Dra. Claudia M.C. Mori (FMVZ), e Silvia Massironi (ICB) pela enorme ajuda com a manutenção, manejo e aprendizado com os modelos murinos.

À Dra. Maria Angélica Miglino, Caju e equipe de vetrinarios da FVST-USP, pela dedicação e ajuda nos projetos com os cães.

Ao Dr. José Roberto Kfoury, amigo e colaborador, que tanto ajudou no preparo de nossos primeiros anticorpos.

Ao Drs. Dr. José Xavier Neto e José Eduardo Krieger, do INCOR-FMUSP, por gentilmente nos ceder o modelo de camundongo gfp.

Ao Dr. Brian E. Strauss (INCOR), pela colaboração com o vetor lentiviral GFP.

Ä Dra. Lygia da Veiga Pereira, pela colaboração no estudo das células trônco embrionárias murinas.

Aos Dr. Irina e Alexandre Kerkis, por um inicio de colaboração muito produtiva no estudo do potencial terapêutico de células tronco em modelos murinos.

À FAPESP, CNPq, PRONEX pelo auxilio financeiro fundamental...

E finalmente...

Ao meus pais queridos, Lucette e Marcel (in memoria), que sempre se orgulharam de mim, e tanto me ajudaram no dia a dia, fazendo com que eu me dedicasse ao trabalho com mais tranquilidade.

Ao Henrique, meu marido, companheiro, amigo, estimulador máximo, cujo apoio incondicional foi fundamental no desenvolvimento de minha carreira científica.

Aos meus filhos, Leo, Rony, Dina, e Marcelo, e à mais recente agregação à família, Vivian, que desde sempre entenderam a importância do meu trabalho, e nunca me cobraram o tempo que lhes foi tirado.

Eu amo muito todos vocês...

Obrigada!! 


\section{Índice}

$\begin{array}{lr}\text { Ficha catalográfica } & 2\end{array}$

$\begin{array}{lr}\text { Agradecimentos } & 3\end{array}$

$\begin{array}{lc}\text { Introdução } & 6\end{array}$

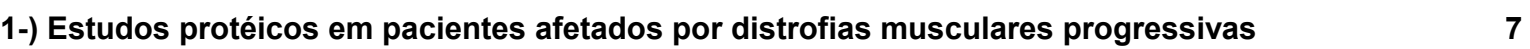

1.1. Distrofia Muscular de Duchenne e Becker 9

$\begin{array}{lr}\text { 1.2. Sarcoglicanopatias } & 12\end{array}$

$\begin{array}{lr}\text { 1.3. LGMD2A } & 14\end{array}$

$\begin{array}{ll}\text { 1.4. LGMD2B } & 16\end{array}$

$\begin{array}{lr}\text { 1.5. LGMD2G } & 17\end{array}$

1.6. A contribuição do estudo de proteínas na identificação de novos genes 18

2-) Estudos de interações entre proteínas no músculo distrófico e normal 19

$\begin{array}{lr}\text { 2.1.SG } & 20\end{array}$

$\begin{array}{lr}\text { 2.2. FKRP } & 21\end{array}$

2.3. Proteínas sarcoméricas $\quad 22$

$\begin{array}{lr}\text { 2.4. Miostatina } & 24\end{array}$

2.5. Estudos em Atletas - Proteínas relacionadas a tipos de fibras 26

3-) Doenças com alterações estruturais na fibra muscular - as miopatias congênitas 28 estruturais

3.1. Central Core (e Hipertermia Maligna) 29

3.2. Miotubular e Centronuclear $\quad 31$

3.3. Nemalinica $\quad 35$

$\begin{array}{ll}\text { 3.4. Distrofias Musculares Congênitas } & 38\end{array}$

4-) Modelos animais $\quad 46$

4.1. Estudos diversos em modelos animais e triagem de novos modelos para doenças 46 neuromusculares.

4.2. O cão distrófico GRMD - caracterização do padrão de degeneração em diferentes músculos e em diversas idades - avaliação da expressão da distrofina, utrofina e miostatina.

4.3. Estudo do potencial miogênico das células tronco mesenquimais e embrionárias em modelos murinos para diferentes formas de distrofias musculares

Resumo

Abstract 


\section{INTRODUÇÃO}

Nos últimos 15 anos, nossa linha de pesquisas tem sido focalizada na expressão de proteínas musculares relacionadas à doenças neuromusculares, avaliando-as quanto à quantidade, localização celular e possíveis interações entre elas. Para entender a função gênica, estudos de correlações genótipo-fenótipo através da análise do efeito de diferentes mutações na expressão da proteína e sua relação com a variabilidade fenotípica são de máxima importância. Além disso, estudos durante o desenvolvimento e em células cultivadas podem nos auxiliar a esclarecer os mecanismos de formação do músculo normal. A identificação de diversos modelos animais para doenças neuromusculares também auxilia significativamente nas pesquisas envolvendo as diferentes vias fisiopatológicas.

1-) Estudos protéicos em pacientes afetados por distrofias musculares progressivas

1.1. Distrofia Muscular de Duchenne e Becker

1.2. Sarcoglicanopatias

1.3. LGMD2A

1.4. LGMD2B

1.5. LGMD2G

1.6. A contribuição do estudo de proteínas na identificação de novos genes

2-) Estudos de interações entre proteínas no músculo distrófico e normal

2.1. SG

2.2. FKRP

2.3. Proteínas sarcoméricas

2.4. Miostatina

2.5. Estudos em Atletas - Proteínas relacionadas a tipos de fibras

3-) Doenças com alterações estruturais na fibra muscular - as miopatias congênitas estruturais

3.1. Central Core (e Hipertermia Maligna)

3.2. Miotubular e Centronuclear

3.3. Nemalínica

3.4. Distrofias Musculares Congênitas

4-) Modelos animais

4.1. Estudos diversos em modelos animais e triagem de novos modelos para doenças neuromusculares.

4.2. O cão distrófico GRMD - caracterização do padrão de degeneração em diferentes músculos e em diversas idades - avaliação da expressão da distrofina, utrofina e miostatina.

4.3. Estudo do potencial miogênico das células tronco mesenquimais e embrionárias em modelos murinos para diferentes formas de distrofias musculares 


\section{1-) Estudos protéicos em pacientes afetados por distrofias musculares progressivas}

As distrofias musculares progressivas constituem um grupo de doenças neuromusculares bastante complexo e heterogêneo, onde se observa uma degeneração progressiva e irreversível da musculatura esquelética do organismo. As distrofias de Duchenne (DMD) e Becker (DMB) afetam somente indivíduos do sexo masculino e são determinadas por um loco em Xp21, que codifica a proteína distrofina As distrofias musculares do tipo Cinturas (DMCs), por outro lado, são causadas por mutações em diversos genes que codificam proteínas musculares estruturais, citoplasmáticas e sarcoméricas, mostrando heterogeneidade genética. A instalação dos primeiros sintomas pode ocorrer na infância, adolescência ou na idade adulta e a progressão da doença é extremamente variável. As diversas formas de DMC foram classificadas de acordo com a cronologia de sua identificação e com o mecanismo de herança envolvido, que pode ser autossômico dominante ou recessivo.

As formas autossômicas dominantes (classificadas como DMC1) correspondem a menos de 10\% dos casos, enquanto que as formas autossômicas recessivas (classificadas como DMC 2) representam mais de $90 \%$ dos casos diagnosticados (tabela 1 ).

Foram descritas até a presente data seis formas de DMC autossômicas dominantes, denominadas de $1 \mathrm{~A}$ até $1 \mathrm{~F}$, as quais foram associadas respectivamente com os genes localizados nas regiões 5q22-q34 (proteína miotilina), 1q11-21 (laminina A/C), 3p25 (caveolina 3), 6q23, 5q31 e 7q (revisão em Vainzof et al, 2003).

As DMC autossômicas recessivas estão geralmente associadas à degeneração e fraqueza da musculatura proximal, e com grande variabilidade clínica. Até o momento foram identificadas mutações em dez genes e o produto protéico de todos já é conhecido. Quatro delas, chamadas DMC2C, 2D, 2E e 2F foram associadas a mutações nas regiões $17 q 21,4 q 12,13 q 12$ e $5 q 33$, relacionadas respectivamente com a expressão das proteínas $\alpha$-sarcoglicana ( $\alpha-S G$ ), $\beta$-SG, $\gamma$-SG e $\delta$-SG, que fazem parte do sub-complexo sarcoglicano, intimamente responsável pela integridade das fibras musculares (figura 1). As cinco formas restantes são a do tipo 2A, 2B, 2G, 2H, 2l e 2J, e 2K, associadas respectivamente a mutações em genes que codificam as proteínas calpaína-3 (15q15.1), disferlina (2p31), teletonina (17q11), TRIM32 (9q31-33), FKRP (fukutin related protein) (19q), titina (2q) e POMT1 (Vainzof e col., 2003; Zatz e col., 2003; DÁmico e col., 2006).

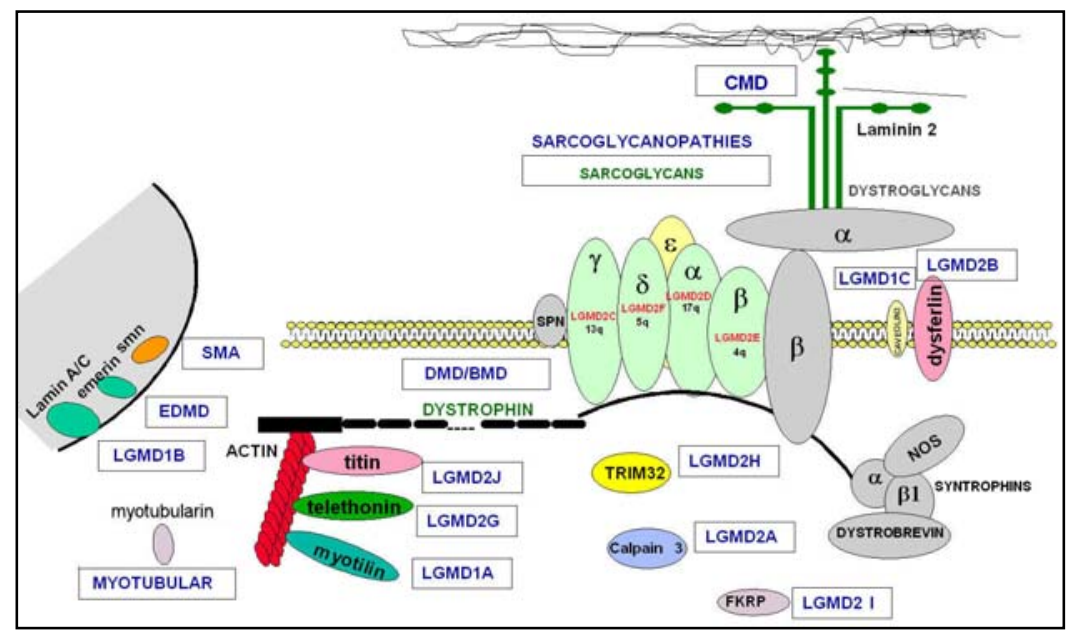

Figura 1: Esquema das proteínas de uma célula muscular com as respectivas doenças neuromusculares associadas (Vainzof e col., 2003). 
Tabela 1- Tipos de DMCs identificadas com suas respectivas localizações cromossômicas dos genes clonados e/ou mapeados e proteínas alteradas.

\begin{tabular}{|c|c|c|c|}
\hline Forma & $\begin{array}{l}\text { Localização } \\
\text { cromossômica }\end{array}$ & $\begin{array}{c}\text { Proteína } \\
\text { correspondente }\end{array}$ & MIM \\
\hline \multicolumn{4}{|c|}{ 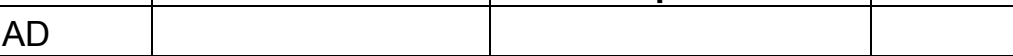 } \\
\hline DMC1A & $5 q 22-q 34$ & Miotilina & $\underline{159000}$ \\
\hline DMC1B & $1 q 11-21$ & Laminina $A / C$ & $\underline{159001}$ \\
\hline DMC1C & $3 p 25$ & Caveolina 3 & $\underline{607801}$ \\
\hline DMC1D & $7 q$ & $?$ & $\underline{603511}$ \\
\hline DMC1E & $5 q 31$ & $?$ & \\
\hline DMC1F & $7 q 32$ & $?$ & $\underline{608423}$ \\
\hline DMC1G & $4 p 21$ & $?$ & $\underline{609115}$ \\
\hline \multicolumn{4}{|l|}{$A R$} \\
\hline DMC2A & $15 q 15.1$ & Calpaína-3 & $\underline{253600}$ \\
\hline DMC2B & $2 p 31$ & Disferlina & $\underline{253601}$ \\
\hline DMC2C & $13 q 12$ & $\gamma$-sarcoglicana & $\underline{253700}$ \\
\hline DMC2D & $17 q 21$ & $\alpha$-sarcoglicana & $\underline{608099}$ \\
\hline DMC2E & $4 q 12$ & $\beta$-sarcoglicana & $\underline{604286}$ \\
\hline $\mathrm{DMC} 2 \mathrm{~F}$ & $5 q 33$ & $\delta$-sarcoglicana & $\underline{601287}$ \\
\hline DMC2G & $17 q 11-12$ & Teletonina & 601954 \\
\hline $\mathrm{DMC} 2 \mathrm{H}$ & $9 q 31-33$ & TRIM32 & $\underline{254110}$ \\
\hline DMC2I & $19 q 13.3$ & FKRP & $\underline{607155}$ \\
\hline DMC2J & $2 q 24$ & Titina & $\underline{608807}$ \\
\hline DMC2K & $9 q 34$ & POMT1 & 609308 \\
\hline
\end{tabular}

Não é possível diferenciar as várias formas de DMC apenas por exame clínico. Por isso é importante identificar o defeito molecular primário (a mutação genética responsável) ou a proteína muscular deficiente em cada caso, pois os riscos de repetição da doença na família serão muito diferentes, dependendo do mecanismo de herança envolvido (Vainzof e Zatz, 2003).

Ao longo dos últimos 15 anos, diversos trabalhos foram finalizados no estudo de defeitos protéicos causadores de doenças neuromusculares, tanto para o estabelecimento do diagnóstico como para tentar elucidar os mecanismos fisiopatológicos envolvidos. A partir destes resultados, trabalhos de revisão e capítulos de livros foram publicados.

Trabalhos publicados em cada sub-ítem - (*) anexos na presente tese

* Vainzof Bueno M, Passos-MR, Zatz M. Immunological methods for the analysis of protein expression in neurmuscular diseases. In: Potter, NT: Methods in Molecular Medicine-Neurogenetics: Methods and Protocols. Humana Press Inc., Totowa, NJ, pp 355-378,2003.

Vainzof M, Zatz M. Protein defects in Neuromuscular disorders. Br J Med Biol Res 36(5): 543-555, 2003.

Zatz M, Starling AS, de Paulo F, Vainzof M. The ten autosomal recessive Limb-Girdle Muscular Dystrophies. Neurom. Disord. 13 (7-8):532-44, 2003.

* Vainzof M, Yamamoto LU, Gouveia TLF, Zatz M. The contribution of protein analysis in the diagnosis of neuromuscular diseases. In: Burgess V.N. Trends in Muscular Dystrophy Research. Nova Publisher, USA.,2005

Vainzof M, Zatz M. Muscular dystrophies and protein mutations. (2006) in: Uversky VN and Fink AL., Protein Misfolding, Aggregation and Conformational Diseases. 


\subsection{Distrofia Muscular de Duchenne e Becker}

A distrofia muscular de Duchenne (DMD) afeta $1 \mathrm{em}$ cada 3500 meninos nascidos. A degeneração muscular progressiva leva à fraqueza gradual com perda de deambulação aos 10-12 anos de idade, em média, e à morte, geralmente antes da terceira década de vida, por falha respiratória e cardíaca. A distrofia muscular de Becker (BMD), uma variante alélica da DMD, é a forma menos grave de fraqueza muscular. Ambas são doenças ligadas ao X causadas por mutação - deleções, duplicações ou mutações de ponto - no gene da proteína distrofina (Koenig e col., 1988, 1989).

Após a descoberta da distrofina o seu estudo no Brasil foi implantado em nosso laboratório e foi feita uma caracterização dos pacientes com distrofias de Duchenne e Becker de nossa população (Vainzof e col., 1990; 1991a,1991b). Os nossos resultados mostraram que apesar da descrita deficiência total de distrofina em pacientes com DMD, ocorre uma pequena expressão da proteína na maioria dos pacientes, o que posteriormente passou a se chamar de fibras revertentes.

Algumas famílias com vários pacientes discordantes quanto ao quadro clínico ajudaram a mostrar que pode ocorrer uma variabilidade intrafamilial na expressão da distrofina, altamente correlacionada com o quadro clínico dos pacientes (Vainzof e col., 1993a).

Com a descoberta da proteína homóloga à distrofina chamada inicialmente de DRP - dystrofin related protein, e posteriormente de utrofina, alguns pesquisadores começaram a sugerir a possibilidade de utilizar a super-expressão da utrofina como possível substituta da distrofina para fins terapêuticos (Khurana e Davies, 2003). Nós estudamos a utrofina por imunohistoquímica em um grande grupo de pacientes com DMD, de diferentes idades e quadro clínico, e verificamos que todos, independentemente do quadro clínico, idade ou quadro histopatológico, apresentavam uma expressão significativa da utrofina na membrana das fibras musculares. Estes resultados nos levaram a sugerir que pacientes com DMD já expressam naturalmente muita utrofina, e que esta não leva a algum benefício clínico (Vainzof e col.1995).

Estudos de distrofina em amostra grande de pacientes candidatos também possibilitaram a identificação dos pacientes com quadro $D M D$-like, mas com a proteína presente, sugerindo a forma autossômica da DMD (Vainzof e col., 1991).

O estudo dos domínios funcionais da distrofina ganhou um impulso significativo com o início dos estudos de terapia gênica. Isto porque o gene da distrofina é grande demais para ser inserido em um vetor, e se fez necessário avaliar quais porções da distrofina são fundamentais para o bom funcionamento do músculo, para a construção de mini-genes funcionais.

A importância do domínio C-terminal da distrofina já estava bem determinado, por ser o local de ligação ao complexo de proteínas e glicoproteínas da membrana sarcolemal. O estudo da distrofina em dois irmãos com quadro grave de DMD mostraram entretanto que não bastava a presença do domínio C-terminal para a manutenção de quadro clínico mais benigno. Nestes dois pacientes, com deleção em fase dos exons 3 a 31 do gene da distrofina, o estudo da proteína no músculo identificou uma molécula pequena, de $320 \mathrm{kDa}$, com manutenção do domínio C-terminal,, mas ausência do domínio $\mathrm{N}$-terminal. Estes resultados mostraram que a presença do domínio $\mathrm{N}$-terminal da distrofina era também muito importante, já que neste domínio há um sítio de ligação à actina, completando desta forma a ligação entre as proteínas contráteis no interior da fibra muscular com a matriz extra-celular em seu exterior (Vainzof e col. 1993). 
Um paciente com BMD com quadro extremamente benigno e deleção de $50 \%$ do gene na região do domínio em bastão do gene da distrofina (exons 17 a 48) ajudou a demonstrar a importância redundante desta região da proteína para o bom funcionamento do músculo. A análise da distrofina no músculo mostrou a presença de uma molécula de proteína de $200 \mathrm{kDa}$ relativamente estável, mantendo funcionais os domínios N- e C-terminal da proteína (Passos Bueno e col., 1994).

Em diversos estudos posteriores, caracterizamos um fragmento adicional de distrofina de cerca de 250 $\mathrm{kDa}$, em pacientes com distrofia de Becker e deleções com início no exon 45. Esta distrofina alterada foi considerada como uma fragmento de síntese intermediária, pois correspondia exatamente ao tamanho de peptídeo esperado para a tradução dos exons 1 a 45 (Vainzof e col., 1992). Alem disso, estudamos a distrofina em algumas famílias com vários pacientes com BMD e padrão de herança claramente ligada ao $\mathrm{X}$, sem deleção identificada no gene da distrofina. Verificamos que alguns dos pacientes mostraram banda de distrofina em quantidade compatível com o normal, considerando-se as margens de variabilidade da metodologia. Estes resultados sugeriram portanto que a distrofia tipo Becker era compatível também com níveis de distrofina bem próximos ao normal, o que tem importantes implicações para o diagnóstico diferencial e aconselhamento genético das famílias (Vainzof e col., 1995).

Diversos estudos da distrofina foram também realizados em heterozigotas para o gene da DMD e mostraram que enquanto as portadoras manifestantes de fraqueza muscular apresentavam um padrão em mosaico de fibras positivas e negativas para a distrofina, este padrão não era observado nas portadoras não manifestantes (Vainzof e col,m 1991). A importância da presença de distrofina homogeneamente distribuída na fibra muscular foi comprovada em estudos realizados em heterozigotas, mães de pacientes com BMD e portadoras de mutação em fase. A presença de banda de distrofina de tamanho reduzido foi confirmada por estudos de western blot. A distribuição desta distrofina alterada foi então analisada com o uso de anticorpos específicos das regiões presentes e ausentes desta molécula. Com todos os anticorpos avaliados, a distrofina se mostrou presente ao redor de toda a fibra muscular comprovando a sua redistribuição homogênea (Vainzof e col, 1993). Através de maiores estudos destas moléculas pequenas de distrofina alterada pudemos também construir um modelo para a quantificação da distrofina para fins diagnósticos (Vainzof e col., 1992).

Vainzof, M.; Pavanello, R.C.M.; Pavanello, I.; Passos-Bueno, M.R.; Rapaport, D.; Zatz, M. - Dystrophin immunostaining in muscles from patients with different types of muscular dystrophy: A brazilian study J. Neurol. Sci. 98: 221-233, 1990.

* Vainzof, M.; Zubrzycka-Gaarn, E.E.; Rapaport, D.; Passos-Bueno, M.R.; Pavanello, I.; Zatz, M. - Immunofluorescence dystrophin study in Duchenne dystrophy through the concomitant use of two antibodies directed against the carboxi-terminal and the amino-terminal region of the protein. J. Neurol. Sci., 101 (2):141-147, 1991a.

Vainzof, M.; Passos-Bueno, M.R.; Takata, R.I.; Pavanello, R.C.M.; Zatz, M. Intrafamilial variability in dystrophin abundance correlated with difference in the severity of the phenotype. J. Neurol. Sci.119: 38-42, 1993a

* Vainzof, M.; Passos-Bueno, M.R.; Nguyen thi Man, Zatz, M. Absence of correlation between utrophin localization and quantity and the clinical severity in Duchenne Dystrophy (DMD). Am J Med Genet 58;305-309, 1995.

Vainzof, M.; Pavanello, R.C.M.; Pavanello, I.; Rapaport, D.; Passos- Bueno, M.R.; Zubrzycka-Gaarn, E.E.; Bulman, D.; Zatz, M. - Screening of male patients with autosomal recessive Duchenne dystrophy through dystrophin and DNA studies. Am. J. Med. Genet. 39:38-41, 1991

Vainzof, M.; Passos-Bueno, M.R.; Rapaport, D.; Pavanello, R.C.M.; Bulman, D.E,; Zatz, M. Additional dystrophin fragment in Becker muscular dystrphy patients: Correlation with the pattern of DNA deletions. Am. J. Med. Genet., 44:382384, 1992.

* Vainzof, M.; Passos-Bueno, M.R.; Takata, R.I.; Pavanello, R.C.M.; Zatz, M. - Is the maintainance of the C-terminus domain of dystrophin enough to ensure a milder Becker muscular dystrophy phenotype? Hum. Mol. Genet. 2:39-42, 1993

Vainzof, M.; Passos-Bueno, M.R., Pavanello R.C.M., Zatz, M. Is dystrophin always altered in Becker muscular dystrophy patients? J Neurol. Sci. 131:99-104, 1995 
Vainzof, M.; Pavanello, R.C.M.; Pavanello, I.; Tsanaclis, A.M.; Levy, J.A.; Passos-Bueno, M.R.; Rapaport, D.; Zatz, M. Dystrophin immunofluorescence pattern in manifesting and asymptomatic carriers of Duchenne's and Becker muscular dystrophy of different ages. Neuromus. Disord., 1 (3): 177-183, 1991.

Vainzof, M.; Nicholson, L.V.B.; Bulman, D.E.; Tsanaclis, A.M.; Passos-Bueno, M.R.; Pavanello, R.C.M.; Zatz, M. Sarcolemmal distribution of abnormal dystrophin in Xp21 carriers. Neuromusc. Disord. 3: 135-140, 1993.

Vainzof, M.; Passos-Bueno, M.R.; Pavanello, R.C.M.; Schreiber, R.; Zatz M. - A model to estimate the expression of the dystrophin gene in muscle from Becker female muscular dystrophy carriers. J. Med. Genet., 22:476-479, 1992

Passos-Bueno MR, Vainzof M, Marie SK, Zatz M. Half the dystrophin gene is apparently enough for a mild clinical course: confirmation of its potential use for gene therapy. Hum Mol Genet 3:919-922, 1994

\subsection{Sarcoglicanopatias}

Os estudos deste grupo de distrofias começou quando ainda se achava que existia apenas uma proteína interagindo com as outras moléculas sarcoplasmáticas, a adalina. $O$ estudo da adalina foi realizado em colaboração com o seu descobridor, Dr. Kevin Campbell, com o qual continuamos colaborando até hoje. O estudo dos pacientes brasileiros permitiu a identificação de 9 pessoas com deficiência (Zatz e col., 1994). Posteriormente, mutações no gene da adalina foram identificadas nestes mesmos pacientes (Passos-bueno e col., 1995). Entretanto, alguns pacientes que apresentavam a deficiência surpreendentemente mostraram falta de ligação com o loco no cromossomo 17, onde se localizava o gene da adalina, sugerindo heterogeneidade genética (Passos Bueno e col. 1993c). Posteriormente se verificou que de fato, as formas DMD-like eram causadas por deficiências em várias proteínas, que se organizavam em um complexo. Diversos estudos foram realizados neste grupo de pacientes, avaliando o padrão de expressão das proteínas sarcoglicanas, e 3 formas de sarcoglicanopatias adicionais foram caracterizadas a partir dos estudos protéicos realizados em nosso laboratório: DMC2C (MacNally e col., 1996), DMC2E (Bonnemann e col., 1996) e DMC2F, que foi totalmente descrita e caracterizada em pacientes brasileiros (Passos-Bueno e col., 1996; Nigro e col., 1996, Moreira e col., 1998).

Uma vez achado o defeito molecular em grande parte dos pacientes com as formas graves de DMC, e caracterizadas as sarcoglicanopatias, um completo estudo da organização do complexo em pacientes com diferentes mutações nos 4 genes sarcoglicanos foi realizado. Os resultados mostraram que em biópsias musculares de pacientes afetados, a deficiência primária de uma proteína sarcoglicana leva a deficiência secundária de todo o complexo. Particularmente, verificou-se que na deficiência primária de $\gamma$-SG, as outras 3 proteínas estavam parcialmente presentes, sugerindo a sua maior união. $\mathrm{O}$ estudo das sarcoglicanas em pacientes com todas as formas de DMC foram publicados em artigo que mereceu o maior número de citações, tornando-se um trabalho de referência nacional (Vainzof e col., 1996 - ISI- 120 citações em 08/2006).

As sarcoglicanopatias são diagnosticadas em $68 \%$ dos pacientes com fenótipo grave de DMC (Vainzof e col., 1996). Estudos na população brasileira mostraram uma maior prevalência das seguintes mutações nos 4 genes sarcoglicanos: R77C no exon 3 da $\alpha$-SG, mutações no exon 3 da $\beta$-SG, $\Delta 521 \mathrm{~T}$ no exon 6 da $\gamma$-SG e del656C no exon 7 da $\delta$-SG (Passos e col., 1999; Moreira e col., 2003). Em vista destes resultados foi desenvolvida uma técnica de triagem simultânea destas mutações através de método PCR multiplex, que permite a identificação de cerca de $80 \%$ das mutações em pacientes candidatos (Gouveia e col, 2006). Os exons correspondentes a estas mutações foram amplificados em conjunto, e analisados por técnica de SSCP. Dada a alta freqüência das sarcoglicanopatias entre pacientes com quadro clínico mais 
grave de distrofia muscular tipo Cinturas, a triagem de mutações nestes 4 genes se tornou importante para o diagnóstico diferencial, caracterização e estudos fisiopatológicos destas miopatias.

Zatz, M.; Matsumura, K.; Vainzof, M.; Passos-Bueno, M.R.; Pavanello, R.C.M.; Marie, S.K.N.; Campbell, K.P. Assessment of the 50-kDa dystrophin-associated glycoproteins in Brazilian patients with severe childhood autosomal recessive muscular dystrophy. J. Neurol. Sci. 123:122-128, 1994.

Passos-Bueno, M.R.; Oliveira, J.R.; Bakker, E.; Anderson, R.D.; Marie, S.K.; Vainzof, M.; Roberds, S; Campbell, K.P.; Zatz, M. Genetic heterogeneity for Duchenne-like muscular dystrophy (DLMD) based on linkage and 50 DAG analysis. Hum. Mol. Genet. 2: 1945-1947, 1993c.

Passos-Bueno MR, Moreira ES, Vainzof M, Chamberlain J, Marie SK, Pereira LV, Akiyama J, Roberds SL, Campbell KP, Zatz M. A common missense mutation in the adhalin gene in three unrelated Brazilian families with a relatively mild form of autosomal recesiv limb girdle muscular dystrophy. Hum. Mol. Genet. 4 (7): 1163-1167, 1995.

McNalllly E, Passos-Bueno MR, Bonnemann C, Vainzof M, Moreira ES, Lidov H, Ben Othmane K, Denton P, Vance J, Zatz M, Kunkel LM. Mild and Severe muscular dystrophy caused by a single $\gamma$-Sarcoglycan mutation. Am J Hum Genet, 59: 1040-1047, 1996.

Bonnemann CG, Passos-Bueno MR, McNally EM, Vainzof M, Moreira ES, Marie SK, Pavanello RCM, Noguchi S, Ozawa E, Zatz M. Kunkel LM. Genomic screening for $\beta$-sarcoglycan mutations: Missense mutations may cause severe limbgirdle muscular dystrophy type 2E (LGMD 2E). Hum Mol Genet 5 (12): 1953-1961, 1996.

Passos-Bueno MR, Moreira ES, Vainzof M, Marie SK, Zatz M. Linkage analysis in autosomal recessive limb-girdle muscular dystrophy maps a sixth form to 5q33-34 (LGMD2F) and indicates that there is at least one more subtype of AR LGMD. Hum Mol Genet 5: 815-820, 1996.

* Nigro V, Moreira, ES, Piluso G, Vainzof M, Belsito A, Politano L, Puca AA, Passos-Bueno MR, Zatz M. The 5q autosomal recessive limb-girdle muscular dystrophy (LGMD2F) is caused by a mutation in the $\delta$-sarcoglycan gene. Nature Genetics 14: 195-198, 1996

Moreira ES, Vainzof M, Marie SK, Nigro V, Zatz M, Passos-Bueno MR. A first missense mutation in the $\partial$-sarcoglycan gene associated with a severe phonotype and frequency of limb-girdle muscular dystrophy type $2 F$ (LGMD2F) among Brazilian sarcoglycanopathies. J. Med. Genet. 35:951-953, 1998.

* Vainzof M, Passos-Bueno MR, Moreira ES, Pavanello RCM, Marie SK, Andreson LVB, Bonnemann CG, McNally EM, Nigro V, Kunkel LM, Zatz M. The sarcoglycan complex in the six autosomal recessive limb-girdle (AR LGMD) muscular dystrophies. Hum Mol Genet, 5 (12): 1963-1969, 1996.

* Vainzof M, Passos-Bueno MR, Pavanello RCM, Marie SK, Zatz M. Sarcoglycanophathy is responsible for $68 \%$ of severe autosomal recessive limb-girdle muscular dystrophy. J. Neurol. Sci 164 (1): 44-49, 1999.

Passos-Bueno MR, Vainzof M, Moreira ES, Zatz M. Seven autosomal rcessive limb-girdle muscular dystrophies in the brazilian population: From LGMD2A to LGMD2G. Am.J.Med.Genet. 82:392-398, 1999

Moreira ES, Vainzof M, Suzuki OT, Pavanello RC, Zatz M, Passos-Bueno MR.Genotype-phenotype correlations in 35 Brazilian families with sarcoglycanopathies including the description of three novel mutations. J Med Genet. 40(2):E12. 2003

* Gouveia TL, Paim JFO, Pavanello RCM, Zatz M, Vainzof M. . Sarcoglycanopathies: A multiplex analysis for the most common mutations. Diag. Mol. Pathol. In press, 2006

\subsection{LGMD2A}

A forma DMC2A é causada por mutações no gene da calpaína 3 localizado no cromossomo 15q15., que é uma protease muscular de $94 \mathrm{kDa}$, ativada pelo cálcio. A função específica desta enzima ainda não está bem determinada, mas sugere-se que tenha um papel importante na desagregação de proteínas sarcoméricas. Imagina-se que também tenha um papel regulatório na modulação de fatores de transcrição. Os pacientes com DMC2A apresentam um largo espectro de mutações, distribuídas ao longo de todo o gene. Entretanto, estudo realizado nos pacientes brasileiros com deficiência da proteína no músculo identificaram mutações prevalentes, concentradas em 6 exons (de Paula e col. 2002). Pacientes com mutações confirmadas no gene CAPN3 podem entretanto apresentar deficiências totais, parciais ou imperceptíveis no nível da proteína, sem correlação significativa com o quadro clínico (Spencer e col., 1997; Vainzof e col., 1999; 2000; de Paula e col., 2002). Alem disso, a variabilidade clinica pode ser tão ampla que pacientes inicialmente diagnosticados com uma forma de atrofia neurogênica e níveis de enzimas séricas normais 
foram identificados posteriormente como portadores de DMC2A, com uma mutação de sentido trocado em homozigose, e ausência da proteína em biopsia muscular (Starling e col, 2003). Uma segunda família apresentou sobreposição com o diagnóstico de síndrome de Mc Leod, de herança ligada ao X (Starling e col., 2005). Estes resultados sugerem que o espectro de variabilidade clinica em cada forma genética é bem mais amplo do que suspeitado.

A expressão da calpaína 3 é normal no músculo de pacientes com DMD/BMD, sarcoglicanopatias e DMC2G (Vainzof e col., 2000; 2001; 2002). Entretanto, uma redução secundária de calpaína 3 em pacientes DMC2B com deficiência de disferlina foi encontrada tanto em pacientes brasileiros (Vainzof e col., 2001) como em pacientes da Europa (Anderson et al., 2000), sugerindo uma possível associação entre estas duas proteínas.

A análise histopatológica do músculo dos pacientes com DMC2A mostra alterações típicas de um processo distrófico primário, com degeneração, fibras fendidas, centro-nucleadas, focos de regeneração, infiltrado inflamatório e substituição das fibras degeneradas por tecido conjuntivo e adiposo perimisial e endomisial. Entretanto, estudo realizado em alguns pacientes assintomáticos ou nos estágios muito iniciais da doença mostrou um padrão atípico de início de degeneração, com fascículos isolados em degradação, perdendo proteínas sarcolemais, circundados por fascículos musculares totalmente normais. Estes achados foram observados em pacientes com diferentes mutações no gene CAPN3, e com deficiências totais e parciais da proteína no músculo, confirmando que este padrão de início de degeneração independe destes fatores (Vainzof e col., 2003).

Vainzof M, Anderson LVB, Moreira ES, Passos-Bueno MR, Pavanello RCM, Zatz M. LGMD2A: muscle calpain analysis in Brazilian LGMD patients. 4th International Congress of the World Muscle Society. Antalya, Turquia, 14-16 outubro de 1999. Neurom.Disord. 9: 506, 1999.

Vainzof M, Anderson LVB, Moreira ES, Passos-Bueno MR, Pavanello RCM, Zatz M. Calpain 3: Characterization of the primary defect in LGMD2A and analysis of its secondary effect in other LGMDs. 52nd annual Meeting of the American Academy of Neurology. San Diego, CA, 29/4-6/5, 2000. Neurology 54: A436, 2000.

Spencer MJ, Tidball JG, Anderson LVB, Bushby KMD, Harris JB, Passos-Bueno MR, Somer H, Vainzof M, Zatz M. Absence of calpain 3 in a form of limb-girdle muscular dystrophy (LGMD2A). J. Neurol. Sci., 146: 173-178, 1997.

de Paula f, Vainzof M, Passos-Bueno MR, Pavanello RCM, Matioli SR, Anderson LVB, Nigro V, Zatz M. Clinical variability in calpainopathy: what makes the difference? Eur J. Hum. Genet. 10 (2): 825-32, 2002

Starling A, Paula F, Silva H, Vainzof M, Zatz M. Calpainopathy: how broad is the spectrum of clinical variability? J Mol Neurosc 21:233-236, 2003

* Starling A, Schlesinger D, Kok F, Passos-Bueno MR, Vainzof M, Zatz M. A family with McLeod syndrome and calpainopathy with clinically overlapping diseases. Neurology 13;65(11):1832-3. 2005.

Vainzof M, Pavanello RCM, Anderson LVB, Moreira ES, Passos-Bueno MR \& Zatz M (2001). Dysferlin analysis in autosomal recessive limb-girdle muscular dystrophies (AR-LGMD). Journal of Molecular Neuroscience, 17: 71-80.

Vainzof M, Moreira ES, Passos-Bueno MR e cols (2002). The effect of telethonin deficiency in LGMD-2G and its expression in other forms of muscular dystrophies and congenital myopathies. Biochimica et Biophysica Acta Genetic Basis of Diseases, 1588: 33-40.

* Vainzof M, de Paula F, Tsanaclis AM, Zatz M. The effect of calpain 3 deficiency in the pattern of muscle degeneration in the earliest stages of LGMD2A. J. Clinical Pathol, 56: 624-626, 2003.

\subsection{LGMD2B}

Esta forma de distrofia é causada por mutações em gene localizado no cromossomo $2 p 12-14$, que codifica a disferlina, proteína de $230 \mathrm{kDa}$. Mutações neste mesmo gene foram também encontradas na forma de miopatia distal de Miyoshi (Mahjneh e col., 1996). A disferlina é expressa ubiquitiosamente, e, no músculo, se ancora no sarcolema. 
O gene da disferlina é muito grande, composto por 55 exons, o que dificulta o seu estudo. Por isso, até a presente data, poucas mutações foram identificadas em pacientes candidatos.

Por outro lado, a proteína disferlina já foi muito estudada, principalmente por técnica de western blot, onde o resultado é muito mais confiável, visto que os anticorpos disponíveis até agora não possibilitam uma análise muito precisa por técnica de imunohistoquímica (Vainzof e col. 2001). Estudos da disferlina em pacientes com DMC2B mostraram que a grande maioria dos pacientes apresenta deficiência total da proteína no músculo (Vainzof e col., 2001), embora algumas deficiências parciais já foram descritas (Anderson e col., 1999). Estudos quantitativos de disferlina em biópsias musculares de pacientes com DMD/BMD, sarcoglicanopatias, DMC2A e DMC2G mostraram níveis normais da proteína, sugerindo que a deficiência de disferlina é específica a DMC2B, e que a disferlina aparentemente não interage com a distrofina, sarcoglicanas, calpaína 3 ou proteínas sarcoméricas como a teletonina (Vainzof e col., 2001). Por outro lado, sugere-se uma relação entre a disferlina e a caveolina 3 (Minetti e col., 1998), cuja deficiência primaria causa uma rara forma de distrofia muscular dominante tipo $1 \mathrm{C}$.

Estudos muito recentes vêm associando a função da disferlina com a fusão de membranas e atribuem a esta proteína um importante papel na miogênese (Campbell e col., 2005).

* Vainzof M, Anderson LVB, McNally EM, Davis DB, Faulkner G, Moreira ES, Pavanello RCM, Passos-Bueno MR, Zatz M. Dysferlin protein analysis in limb-girdle muscular dystrophies. J Mole. Neurosc. 17:71-80, 2001.

Mahineh I, Passo-Bueno MR, Zatz M, Vainzof M, Marconi G, Nashef L, Bashir R, Bushby K. The phenotype of chromosome 2p-linked limb-girdle muscular dystrophy. Neurom. Disord. 6: 483-490, 1996.

\subsection{LGMD2G}

A teletonina é uma proteína sarcomérica de aproximadamente $19 \mathrm{kDa}$, localizada na banda $Z$ do sarcômero dos músculos estriados esqueléticos e cardíacos adultos, onde interage com a proteína titina. $\mathrm{O}$ gene da teletonina (TCAP) está localizado na região 17q11-12 e possui dois exons. Mutações no gene da teletonina causam distrofia muscular das Cinturas tipo 2G (DMC-2G), uma forma de distrofia mais branda, com grande variabilidade clínica. Esta forma de distrofia foi identificada em nossos laboratórios (Moreira e col., 1997; 2000). Estudos protéicos posteriores mostraram que a deficiência de teletonina é específica de DMC2G, sem reduções secundárias em outras formas de distrofias (Vainzof e col, 2002).

Todos os pacientes estudados até a presente data, pertencentes a 4 famílias, apresentaram a mesma mutação truncada (em homozigose, ou em heterozigose composta) e ausência da proteína no músculo. O possível efeito de outras mutações neste gene é desconhecido. Por isso, triamos para mutações no gene da teletonina uma amostra grande de pacientes com distrofias mais heterogêneas clinicamente. Dentre os 200 pacientes triados, identificamos 3 novas famílias, portadoras da mesma mutação identificada nas famílias iniciais. Este constituiu o trabalho de conclusão de curso do aluno Bruno Lima (Lima e col, 2004, 2005).

Moreira ES, Vainzof M, Marie SK, Sertie AL, Zatz M, Passos-Bueno MR. The seventh form of autosomal recessive limbgirdle muscular dystrophy is mapped to 17q11-12. Am. J.Hum.Genet. 61: 151-159, 1997.

* Moreira ES, Wiltshire TJ, Faulkner G, Nilforoushan A, Vainzof M, Suzuki OT, Valle G, Reeves R, Zatz M, Passos-Bueno MR, Jenne D. Limb-girdle muscular dystrophy type 2G (LGMD2G) is caused by mutations in the gene encoding the sarcomeric protein telethonin. Nature Genet. 24:163-166, 2000.

* Vainzof M, E.S. Moreira, M.R. G. Faulkner, G. Valle, E., A. Beggs, O. Carpen, A.F. Ribeiro, E. Zanoteli, J. GurgelGianneti, A.M. Tsanaclis, Helga C.A. Silva, M.R. Passos-Bueno, M. Zatz. Telethonin expression in Limb girdle muscular .BBA - Biochim Biophys Acta 1588(1):33-38,2002 
Lima BL, Gouveia TL, Zatz M, Pavanello RCM, Vainzof M. Estudo molecular do gene da teletonina em pacientes com distrofias musculares das cinturas. 120 Simpósio Internacional de Iniciação científica da Universidade de São Paulo. Ribeirão Preto, 23-24 de novembro de 2004-11-05

*Lima BL, Gouveia TL, Pavanello RC, Faulkner G, Valle G, Zatz M, Vainzof M. LGMD2G: screening for mutations in a large sample of Brazilian patients allows the identification of new cases. 10th International Congress of the World Muscle Society, Iguassu Falls, Brazil, September 28 to October 1, 2005. Neurom Disord 15: 687,2005

\subsection{A contribuição do estudo de proteínas na identificação de novos genes}

Diversos estudos de proteínas realizados em nossa rotina diagnóstica de doenças neuromusculares permitiram a identificação de pacientes com deficiências específicas de proteínas musculares. Esta amostra de pacientes foi muito importante para os diversos estudos de ligação que foram realizados em nossos laboratórios, que auxiliaram na identificação de muitos genes causadores de distrofias musculares progressivas. Inicialmente, excluiu-se o loco em $6 q$ do gene da utrofina como candidato a distrofias musculares autossômicas recessivas (Passos-Bueno e col, 1990). Estudos genéticos e clínicos realizados em 22 famílias com formas AR comparou o quadro clínico com as formas ligadas ao X (Passos-Bueno e col., 1991; 1996).

A caracterização clinica minuciosa, e a obtenção de DNA de muitos pacientes afetados de uma mesma família permitiram também a realização dos estudos de ligação para as formas DMC2A (Passos Bueno e col., 1993), LGMD2B no loco 2p (Passos-Bueno e col., 1995), bem como na confirmação de heterogeneidade genética em varias formas de DMC-AR (Passos-Bueno e col., 1993a, 1993b).

Passos-Bueno, M.R., Terwilliger, J., Ott, J., Love, D., Vainzof, M., Davies, K.E., Zatz, M. (1990): Linkage analysis in families with autosomal recessive Limb-girdle muscular dystrophy and 6q probes flanking the dystrophin-related sequnce. Am. J. Med. Genet., 38: 140-

Passos-Bueno, M.R., Vainzof, M., Pavanello, R.C.M., Pavanello-Filho, I., Lima, M.A.B.O., Zatz M (1990): Limb-girdle syndrome: a genetic study of 22 large Brazilian families: comparison with X-linked Duchenne and Becker dystrophies. J. Neurol. Sci. 103:65-75, 1991.

Passos-Bueno, M.R.; Richard, I.; Vainzof, M.; Fougerouse, F.; Weissenbach, J.; Broux, D.; Cohen, D.; Guilherme, L.; Kalil, J.; Zatz, M.; Backmann, J.S. - Evidence of genetic heterogeneity for the autosomal recessive adult forms of limbgirdle muscular dystrophy following linkage analysis with 15q probes in Brazilian families. J. Med. Genet.30: 385387, 1993a.

Passos-Bueno, M.R.; Beckmann, J.; Vainzof, M.; Pavanello, R.C.M.; Marie, S.K.; Zatz, M. - Exclusion of the 15q locus as a candidate gene for severe childhood autosomal recessive Duchenne-like muscular dystrophy in Brazilian families. Hum. Mol. Genet. 2:201-202, 1993b.

Passos-Bueno MR, Bashir R, Moreira ES, Vainzof M, Marie SK, Vasquez L, lughetti P, Bakker E, Keers S, Stephenson A, Strachan T, Mahneh I, Weissenbach J, Bushby K, Zatz M. Confirmation of the 2p locus for mild autosomal recessive limb-girdle muscular dystrophy in three families allows refinement of the candidate region. Genomic , 27: 192-195, 1995

Passos-Bueno MR, Moreira ES, Marie SK, Bashir R, Vasquez L, Love DR, Vainzof M, iughetti P, Oliveira JR, Bakker E, Strachan T, Bushby K, Zatz M. Main clinical features for the three mapped autosomal recessive limb girdle muscular dystrophies and estimated proportion of each form in 13 brazilian families. J. Med. Genet. 33:97-102, 1996.

\section{2-) Estudos de interações entre proteínas no músculo distrófico e normal}


A proteína muscular distrofina constitui um dímero anti-paralelo, com o domínio C-terminal como sítio de ligação à membrana, através de seu complexo de glicoproteínas associadas (DGC), e o domínio Nterminal como ponto de ligação com os filamentos de actina.

Baseando-se em seu grau de solubilização, o complexo de DGC purificado a partir de músculo esquelético de coelho foi dividido em três sub-complexos. O complexo distroglicano é composto por $\alpha$ distroglicana e $\beta$-distroglicana, que são codificadas por um mesmo gene no cromossomo 3q. O complexo DG atravessa o sarcolema, formando uma conexão entre a matriz extracelular e o citoesqueleto (Ervasti e Campbell, 1993). Não foi descrita ainda nenhuma doença humana associada a alterações nas proteínas deste sub-complexo, mas ele apresenta deficiências secundárias, relacionadas com algumas formas de distrofias musculares. O segundo sub-complexo sarcoglicano é composto pelas glicoproteínas $\alpha-, \beta-., \gamma-$ e $\delta$ sarcoglicanas que são codificadas por genes nos cromossomos 17q, 4q, 13q e 5q. Mutações nestes genes são responsáveis respectivamente pelas DMC-2D, DMC-2E, DMC-2C e DMC-2F, chamadas também de sarcoglicanopatias (Revisão em Bonnemman et al. 1996). Finalmente, o complexo sintrofinas é composto pelas proteínas de 59 kDa, ou 59 DAP, ou A1, (Campbell \& Kahl, 1989; Ervasti \& Campbell, 1991; Yoshida \& Ozawa, 1990;)

Observações de que na DMD, o nível de todas as DAGs está reduzido, enquanto que na BMD ocorre geralmente uma redução mais suave das DAPs, o que tem levado ao consenso de que a distrofina localiza ou estabiliza o complexo DGC. Por outro lado, nas sarcoglicanopatias observamos deficiências do complexo todo (Vainzof e col., 1996), com as exceções descritas a seguir. Estudos realizados nas diversas formas de distrofias já classificadas mostraram que as deficiências de teletonina e disferlina são específicas para DMC2G e DMC2B (Vainzof e col., 2002; 2001), enquanto a deficiência de calpaína 3 pode ser primaria ou secundária (Vainzof e col.,2000).

\footnotetext{
* Vainzof M, Anderson LVB, Moreira ES, Passos-Bueno MR, Pavanello RCM, Zatz M. Calpain 3: Characterization of the primary defect in LGMD2A and analysis of its secondary effect in other LGMDs. 52nd annual Meeting of the American Academy of Neurology. San Diego, CA, 29/4-6/5, 2000. Neurology 54: A436, 2000.

* Vainzof M, Pavanello RCM, Anderson LVB, Moreira ES, Passos-Bueno MR \& Zatz M (2001). Dysferlin analysis in autosomal recessive limb-girdle muscular dystrophies (AR-LGMD). Journal of Molecular Neuroscience, 17: 71-80.

* Vainzof M, Moreira ES, Passos-Bueno MR et al. (2002). The effect of telethonin deficiency in LGMD-2G and its expression in other forms of muscular dystrophies and congenital myopathies. Biochimica et Biophysica Acta Genetic Basis of Diseases, 1588: 33-40.
}

\subsection{Sarcoglicanas}

O complexo sarcoglicano se comporta como uma unidade, visto que em pacientes com sarcoglicanopatias a deficiência primária de qualquer uma das 4 proteínas leva à deficiência secundária do complexo todo. Exceções foram posteriormente identificadas em pacientes com deficiência de somente $\gamma$-SG e $\alpha$-SG, com retenção de todo o complexo (Vainzof e col., 1999; 2000). Entretanto, não foi observada correlação entre a retenção das proteínas do complexo sarcoglicano e o quadro clínico dos pacientes (Vainzof e col., 1996).

As proteínas sarcoglicanas se caracterizam por estarem fortemente interligadas no complexo, comprovado pela observação de que a deficiência primária de qualquer uma delas leva à deficiência do complexo todo na membrana das fibras musculares. As proteínas sarcoglicanas formam um complexo tetramérico na proporção de 1:1:1:1 (Jung et al, 1996). O complexo sarcoglicano (SG) é sintetizado e 
formado no retículo endoplasmático (RE), não ocorrendo associação com o complexo distroglicano (DG) nem com sarcospan no RE. Essa associação ocorre durante a translocação dos componentes do SG e DG via complexo de Golgi para a membrana celular. (Nogushi et al, 2000). Experimentos utilizando sistema de células heterólogas demonstrou que as SGs são glicosiladas quando reunidas no complexo que reside na membrana plasmática e que a montagem do complexo é dependente da síntese simultânea das quatro SGs. Experimentos com SGs mutantes bloquearam a formação e a inserção do complexo na membrana plasmática, reforçando a idéia que o defeito molecular das sarcoglicanopatias consistiria na falta de montagem ou do tráfego incorretos do complexo SG, induzindo a ausência do complexo no sarcolema (Holt et al, 1998). O estudo da interligação entre as proteínas sarcoglicanas ainda necessita de maiores análises. $O$ estudo de pacientes com as diferentes formas de sarcoglicanopatias pode ajudar a elucidar o mecanismo de formação, inserção e localização do complexo na fibra muscular. De fato, muito recentemente, identificamos um paciente com LGMD2F e quadro clínico benigno que apresentou na biópsia muscular deficiência de somente $\delta$-SG, e retenção das outras 3 proteínas sarcoglicanas. Este resultado foi surpreendente e sugere pela primeira vez que o complexo sarcoglicano pode se organizar mesmo na ausência da $\delta$-SG (Gouveia e col., 2006 - submetido para publicação).

* Vainzof M, Moreira ES, Ferraz G, Passos-Bueno MR, Marie SK, Zatz M. Further evidences for the organization of the four sarcoglycans proteins within the dystrophin-glycoprotein complex. Eur. J. Hum Genet 7:251-254, 1999

* Vainzof M, Moreira ES, Canovas M, Suzuki OT, Pavanello RCM, Costa CS, Passos-Bueno MR, Zatz M. Partial $\alpha$ sarcoglycan deficiency associated with the retention of the SG complex in a LGMD2D family. Muscle\&Nerve, 23: (6) 984-988, 2000.

Telma L.F.Gouveia - Dissertação de mestrado "Estudo da organização das proteínas sarcoglicanas em células musculares em culturas, derivadas de pacientes afetados por DMC tipo sarcoglicanopatias". Programa de biotecnologia. . Defesa: 25/04/05 Bolsa FAPESP Proc. 01/11774-0.

* Gouveia TLF, Paim JFO, Zatz M, Vainzof M. "In vivo" evidences for the sarcoglycan complex organization in the sarcolemma in spite of the primary absence of $\delta$-SG. Submitted, 2006.

\subsection{FKRP}

Recentemente, verificou-se que mutações no gene FKRP causam duas formas clinicamente distintas de DMPs: a forma grave de distrofia muscular congênita (CMD1C) bem como a distrofia muscular das Cinturas tipo 2l (DMC-2l), ambas com padrão de herança autossômica recessiva. Estudos da expressão muscular de proteínas da matriz extracelular, da membrana sarcolemal e da via de glicosilação da $\alpha$ distroglicana ( $\alpha-D G)$ em pacientes com mutações no gene FKRP sugerem anormalidades secundárias na expressão de algumas destas proteínas. Os indivíduos afetados têm uma diminuição importante da $\alpha$ distroglicana no músculo, detectada na reação imunohistoquímica e uma redução no peso molecular pela análise por Western Blot. A proteína $\alpha$-DG, componente do complexo distrofina-glicoproteínas associadas à membrana sarcolemal, é fortemente glicosilada e está associada à laminina 2. Portanto, mutações que interferem com o mecanismo de glicosilação possivelmente alteram esta importante ligação, fragilizando a membrana e tornando a fibra muscular mais vulnerável à degeneração.

Um estudo protéico foi realizado nas biópsias musculares de 13 pacientes com mutações no gene FKRP, e foram analisadas as proteínas sarcolemais distrofina, as 4 sarcoglicanas, disferlina, as proteínas de matriz extracelular $\alpha 2$-laminina e colágeno $\mathrm{VI}$, a teletonina sarcomérica e a calpaína 3 . Observamos 
alterações secundarias de $\alpha 2$-laminina em 8 pacientes, sendo 5 deles com mutação comum C826A no gene FKRP. Três pacientes apresentaram deficiência de calpaína 3 e dois pacientes, deficiência de distrofina. Nossos resultados sugeriram que mutações neste gene, que afeta a glicosilação, também leva à deficiências secundárias de diversas outras proteínas musculares (Yamamoto e col., 2003, 2004).

\footnotetext{
Yamamoto LU, Canovas M, B.L. Lima, F. de Paula, N. Vieira, M. Zatz, M. Vainzof. Muscle proteins alteration in patients with mutations in the Fukutin-Related Protein gene. 53rd annual meeting of the American Society of Human Genetics, Los Angeles, November 4-8, 2003. Am. J. Hum. Genet. 73:556, 2003.

* Yamamoto LU, de Paula F, Pavanello RCM, Vieira N, Zatz M,Vainzof M. LGMD2I - secondary muscle protein alteration in patients with mutations in the Fukutin-Related Protein gene. 9th International Congress of the World Muscle Society, Goteborg, Sweden, September 1-4, 2004. Neuromusc. Disord., 14:579, 2004a.

* Yamamoto LU, Velloso FJ, Santos BHC, Kossugue PM, Fogaça LQC, Vajsar J, Paim JF, Zatz M, Vainzof M. Spectrum of mutations in the Fukutin-Related Protein gene (FKRP) in patients refered as Congenital Muscular Dystrophy. 10th International Congress of the World Muscle Society, Iguassu Falls, Brazil, September 28 to October 1, 2005. Neurom Disord 15: 706, 2005.
}

\subsection{Proteínas sarcoméricas}

As proteínas sarcoméricas são proteínas estruturais que fazem parte dos filamentos finos e grossos do sarcômero. Nos últimos anos, novas proteínas foram identificadas, e sua importância para o bom funcionamento do músculo foi evidenciada por causa das doenças que causam quando mutadas. Mutações nos genes da teletonina, miotilina e titina causam DMC-2G, DMC1A e DMC2J respectivamente. Alem disso, mutações em 5 genes que codificam as proteínas sarcoméricas actina, tropomiosina 3 e 2, troponina T1 e nebulina causam miopatia nemalínica, uma forma de miopatia congênita estrutural que será apresentada posteriormente.

Novas proteínas vêm sendo descobertas nos anos recentes, com função ainda não conhecida. Alguns exemplos são as proteínas ZASP, FATZ e Ankrd2, que foram identificadas através de sistema de duplo híbrido com proteínas sarcoméricas que interagem com a titina. Nós colaboramos no estudo da caracterização da Ankrd2, estudamos a sua distribuição e co-localização no músculo normal e em alguns músculos afetados. O estudo desta proteína em pacientes ainda não classificados, excluídos para as formas conhecidas de DMC não possibilitou a identificação da proteína alterada em nenhum deles (Pallavicini e col., 2001).

Por outro lado, o estudo da recém identificada proteína miopaladina revelou uma redução secundária no músculo de pacientes DMC2G, sugerindo uma associação entre esta proteína e a teletonina (Vainzof e col., 2002).

A DMC1A é causada por mutações no gene TTID (cromossomo 5q31), que codifica a proteína miotilina (498 aminoácidos, $57 \mathrm{kDa}$ ). Clinicamente, o início da fraqueza é mais tardio, com comprometimento inicial da musculatura proximal, evoluindo para a musculatura distal. Cerca de $50 \%$ dos pacientes apresenta também fraqueza faringeal com padrão de fala nasal distinta e desarticulada. A biópsia muscular revela indícios de degeneração como variação no calibre das fibras e presença de vacúolos bordados. A miotilina é uma proteína sarcomérica associada à banda $Z$ e está ligada à $\alpha$-actinina e $\gamma$-filamina. Até a presente data, foram identificadas somente duas famílias com DMC1A e mutações de sentido trocado no gene TTID (T57I e $\mathrm{S} 55 \mathrm{~F})$. Em um dos pacientes com a mutação a proteína miotilina foi estudada no músculo e detectou-se uma banda de $57 \mathrm{kDa}$, em quantidade normal. 
$\mathrm{Na}$ análise histopatológica do músculo, tanto os pacientes com DMC1A como os pacientes com DMC2G se caracterizam pela presença na biópsia muscular de degeneração, variação no calibre das fibras e presença de vacúolos bordados. Para melhor estudar esta alteração, selecionamos dentre nossa amostra de cerca de 140 biópsias musculares de pacientes com distrofias musculares das cinturas, pacientes cujo resultado anatomopatológico revelou a presença de grande quantidade de vacúolos bordados no interior das fibras musculares. Estes pacientes estão sendo triados para mutações no gene TTID, em projeto de pesquisa desenvolvido pela aluna de iniciação científica Patrícia Kossugue (FAPESP). Paralelemente, o estudo da proteína miotilina foi feito por western blot em parte destes pacientes. Em uma paciente de 18 anos com quadro clínico grave identificamos uma deficiência específica da proteína miotilina no músculo. Esta é a primeira descrição de uma deficiência de miotilina na literatura internacional. Entretanto, mesmo após rigorosos estudos moleculares de DNA genômico, DNA extraído do músculo e RNA expresso no músculo afetado com posterior RT-PCR, não conseguimos identificar a mutação no gene TTID que poderia causar esta deficiência, sugerindo que a deficiência da miotilina nesta paciente é secundária a algum outro defeito molecular primário (Kossugue e col., 2002 ou 2003; Vainzof e col.,2004).

\footnotetext{
* Pallavicini A, Koji S, Bean c, Vainzof M, slamon M, levolella C, Bortoletto G, Pacchioni B, Zatz M, Lnafranchi G, Faulkner G, Valle G. Characterization of human skeletal Ankrd2. Biochem Biophys Res Commun 2001 Jul 13;285(2):378-86

Vainzof M, Canovas M, Labeit S, Bang ML, Faulkner G, Valle G, Zatz M. Sarcomeric myopalladin study in limb-girdle muscular dystrophies. Xth Internacional Congress on Neuromuscular Diseases, Vancouver, Canadá, 7-12 julho de 2002. J. Neurol. Sci199:S33, 2002.

Vainzof M, Kossugue PM, Yamamoto LU, Gouveia TLF, Santos BGC, Lima BL Gurgel-Giannetti J, Moza M, Carpen O. Heterogeneity in myotilin expression in a patient with Limb Girdle Muscular Dystrophy. 9th International Congress of the World Muscle Society, Goteborg, Sweden, September 1-4, 2004. Neuromusc. Disord.14:606, 2004
}

\subsection{Miostatina}

A miostatina (GDF8 - growth and differentiation factor 8) é um membro da superfamília de fatores de crescimento $\beta$ (TGF $\beta$ ), e foi definida como regulador negativo (inibidor) do crescimento muscular a partir de experimentos em modelos animais. A proteína miostatina é expressa no músculo esquelético e cardíaco. Camundongos com alelos nulos para este gene apresentam hipermusculatura $(\mathrm{hm})$ sendo 2 a 3 vezes maiores que os normais, demonstrando assim o efeito inibitório da miostatina no desenvolvimento muscular. O GDF-8 possui $91,1 \%$ de homologia entre homem, camundongo e boi sendo assim altamente conservado entre as espécies. Não é conhecido o envolvimento do gene GDF8 com o processo distrófico. Dada a grande participação deste gene na regulação e desenvolvimento do músculo normal, o seu estudo e caracterização no músculo distrófico tornam-se de extrema importância. Nós estudamos a expressão do GDF-8 em fibras musculares de camundongos $\mathrm{mdx}$ de diferentes idades e em diferentes músculos (complexo muscular associado ao gastrocnêmio, temporal e diafragma) para verificar se há expressão diferencial com a idade e entre estes músculos que apresentam padrão degenerativo/regenerativo diferentes entre si. A expressão do gene GDF8 está hiperregulada em camundongos $\mathrm{mdx}$ quando comparados a controles normais. A comparação da expressão de GDF8 nos 3 diferentes músculos mostrou que o gastrocnêmio, que é o músculo com apresentou o maior grau de regeneração, também mostrou o maior padrão de expressão de GDF8, enquanto que a menor expressão foi encontrada no diafragma, que foi o músculo com maior grau de degeneração. Além disso, nossos dados indicaram que a razão entre degeneração/regeneração é 
inversamente proporcional ao padrão de regulação do GDF8 em camundongos mdx. A análise da expressão tanto em pacientes com DMD quanto pacientes com DMB foi baixa, ou seja, não houve correlação com o quadro clínico, na distrofia humana. A hiper expressão do gene GDF8 pode ser um dos fatores que modulam a melhor resposta (regeneração eficiente) do camundongo $\mathrm{mdx}$ ao processo de degeneração muscular (Cleber da Costa Silva - dissertação de mestrado).

Estudos em biópsias musculares sugeriram que a miostatina é expressa preferencialmente em fibras musculares do tipo 1. Na população normal, foram descritos seis polimorfismos diferentes no gene GDF8: um no exon 1 (A55T), quatro no exon 2 (K153R, E164K, I255T, P198A) e um localizado no intron entre os exons 2 e 3 (2-3 -8 pb). Estes polimorfismos foram encontrados em baixa freqüência na população geral, à exceção das substituições A55T e K153R, que foram encontradas com freqüências de 12,5\% e 8-17,9\%, respectivamente. Nos avaliamos a correlação entre os polimorfismos nos exons 1 e 2 do gene GDF8 e a distribuição de tipo de fibras em pacientes afetados por miopatias congênitas e predomínio de fibras tipo 1 maior que $80 \%$. Encontramos freqüência semelhante do polimorfismo K153R em 2/9 (22\%) pacientes com miopatias e em 18/84 indivíduos controle (21,4\%), sugerindo que este polimorfismo não tem efeito modificador na freqüência de tipo de fibras musculares em pacientes com predomínio de fibras tipo 1 (Muniz e col, 2004).

Para verificar a expressão da miostatina em músculos com diferentes padrões de degeneração, está sendo feita uma análise quantitativa de expressão de mRNA da miostatina em diversos músculos do cão afetado GRMD, com mutação no gene da distrofina (Dinorah Zilberztajn, projeto de iniciação científica).

Cleber da Silva Costa. Dissertação de Mestrado: Estudo da expressão do gene GDF8 em tecido muscular de camundongos distróficos mdx e nas distrofias Xp21 humanas. Depto. De Biologia, Instituto de Biociências USP. Defesa: 19/12/2002.

Costa CS, Zatz M, Vainzof M. Estudo da Expressao do gene GDF8 em diferentes músculos de camundongos de linhagem distrófica $(\mathrm{mdx})$. 47o Congresso Nacional de Genética, Águas de Lindoia, SP, 2-5 de outubro de 2001. Genet. Mol. Biol. 24, 2001.

* Costa CS, Campos DA, Zatz M, Vainzof M. GDF8 expression and the degeneration/regeneration process in the mdx mice. 7th International Congress of the World Muscle Society Rotterdam, The Netherlands, 2-5 October, 2002. Neuromuscl. Disord. 12: 766, 2002

Viviane Palhares Muniz. - Dissertação de Mestrado "Estudo de proteínas musculares relacionadas à diferenciaçao de tipo de fibras em atletas". Programa de Biologia-Genética, Depto. De Biologia, Instituto de Biociências USP. Defesa: 2/2/06. Bolsas CAPES e FAPESP

* Muniz VP, Silva HC, Pavanello RCM, Cerqueira A, Zatz M, Vainzof M. Molecular analysis of the myostatin gene in patients with muscle hypertrophy due to genetic congenital myotonia. Neuropediatrics, submetido, 2006

Muniz VP, Silva HCM, Zatz M, Vainzof M. Study of the myostatin gene (GDF8) in patients with muscle hypertrophy due to genetic congenital myotonia. 10th International Congress of the World Muscle Society, Iguassu Falls, Brazil, September 28 to October 1, 2005. Neurom Disord 15: 687, 2005

Muniz VP, Oliveira ASB, M. Vainzof M. Muscular fiber type differentiation and polymorphisms in the myostatin gene (GDF8). 10th International Congress of the World Muscle Society, Iguassu Falls, Brazil, September 28 to October 1, 2005. Neurom Disord 15: 687, 2005.

Viviane Palhares Muniz, Acary de Oliveira, Mariz Vainzof. XXI CONGRESSO BRASILEIRO DE NEUROLOGIA 9 a 14 de outubro de 2004 Brasília - DF

Dinorah Zilberztajn. Projeto Iniciação cientifica: estudo da expressão da miostatina em diferentes músculos do cão distrofico GRMD. FAPESP

\subsection{Estudos em Atletas - Proteínas relacionadas a tipos de fibras}


De acordo com a sua estrutura e composição bioquímica, as fibras musculares esqueléticas podem ser identificadas como do tipo 1, ou fibras lentas, e do tipo 2, ou fibras rápidas. As fibras do tipo 1 são ricas em mioglobina e tem cor vermelho-escura. Sua energia é obtida principalmente da fosforilação oxidativa de ácidos graxos e são as fibras adaptadas para contrações continuadas. As fibras tipo 2 contêm pouca mioglobina, sendo por isso de cor vermelho-claro, e são adaptadas para a contração rápida e descontínua. As fibras tipo 2 podem ser divididas em $2 \mathrm{~A}$ e $2 \mathrm{~B}$, de acordo com suas características funcionais e bioquímicas, sendo as fibras tipo $2 \mathrm{~B}$ as mais rápidas, tendo a glicólise como principal fonte de energia. Os músculos esqueléticos humanos geralmente apresentam proporções diferentes de cada tipo de fibras, de acordo com a sua função. A classificação das fibras é importante para a caracterização de doenças neuromusculares.

As isoformas da $\alpha$-actinina incluem uma forma citoesquelética não muscular, ACTN1, mapeada em 14q22-24 e duas isoformas músculo-específicas, ACTN2 e ACTN3, mapeadas em 1q42-43 e 11q13-14. ACTN2 está presente em todos os tipos de fibras, e ACTN3 está presente somente nas fibras tipo 2: 100\% das fibras $2 \mathrm{~B}$ e $50 \%$ das fibras $2 \mathrm{~A}$ (Beggs et al., 1992).

Embora boas candidatas para doenças neuromusculares, foi recentemente mostrado que a deficiência total da $\alpha$-actinina 3 ocorre em aproximadamente $16 \%$ da população normal, sugerindo um papel redundante para esta proteína no funcionamento muscular. Entretanto, o papel modificador desta proteína em doenças neuromusculares ainda está sendo investigado. Além disso, este polimorfismo pode ter um papel na composição das fibras musculares de atletas.

Nas miopatias congênitas, observa-se um predomínio de fibras tipo 1. Trabalhos recentes sugerem uma possível transformação de fibras do tipo 2 em 1 com a progressão da doença (Wallgreen-Petteron et al., 1999). Estudos em atletas tem demonstrado o efeito de exercícios físicos sobre a transformação dos tipos de fibras musculares, sendo que os exercícios de resistência levariam a uma elevação na proporção de fibras do tipo 1.

Neste trabalho, analisamos a possível transformação de fibras do tipo 2 em tipo 1 em diferentes tipos de atletas, através do estudo da expressão de diferentes proteínas específicas das fibras musculares.

A análise da proteína $\alpha$-actinina 3 se mostrou compatível com o bom desempenho muscular, visto que alguns atletas maratonistas, campeões de suas categorias, apresentaram o polimorfismo em homozigose, com a conseqüente ausência total da proteína no músculo. Este resultado sugere que a ação da $\alpha$-actinina 3 no músculo pode ser redundante, e suprida pela presença da $\alpha$-actinina2 (Zanotelli e col., 2003).

Em estudo posterior, avaliamos a correlação entre os polimorfismos no gene da miostatina a distribuição de tipo de fibras em atletas maratonistas. Encontramos o polimorfismo K153R, em 2 dos 17 atletas estudados $(11,8 \%)$ em comparação aos $21,4 \%$ encontrados na população normal brasileira. A avaliação da freqüência do polimorfismo por grupos raciais mostrou 6/42 (14,3\%) em caucasóides e 10/42 $(23,8 \%)$ em negróides. A análise da biópsia muscular dos atletas mostrou a presença de $66 \%$ de fibras tipo 1 em um atleta com o polimorfismo, e em 5 atletas sem o polimorfismo, foi de $34-63 \%$. Portanto, também nos atletas, não foi observado um possível efeito modificador do polimorfismo K153R com a freqüência de tipo de fibras musculares. Entretanto, a freqüência do polimorfismo foi menor na população de atletas maratonistas em comparação aos controles. Este dado é reforçado pela predominância de atletas negróides, considerando-se que a freqüência do polimorfismo na sub-população negróide normal foi de 23,8\% (Muniz e col, 2005). 
Viviane Palhares Muniz. - Dissertação de Mestrado "Estudo de proteínas musculares relacionadas à diferenciaçao de tipo de fibras em atletas". Programa de Biologia-Genética, Depto. De Biologia, Instituto de Biociências USP. Defesa: 2/2/06. Bolsas CAPES e FAPESP

* Muniz VP, Oliveira ASB, M. Vainzof M. Muscular fiber type differentiation and polymorphisms in the myostatin gene (GDF8). 10th International Congress of the World Muscle Society, Iguassu Falls, Brazil, September 28 to October 1, 2005. Neurom Disord 15: 687, 2005.

* Zanoteli E, Renato M Lotuffo, Acary SB Oliveira, Alan H Beggs, Marta Canovas, Mayana Zatz, Mariz Vainzof. Deficiency of Muscle alpha-Actinin-3 is Compatible with High Muscle Performance J. Molec. Neurosc 20(1):39-42, .2003.

\section{3-) Doenças com alterações estruturais na fibra muscular - as miopatias congênitas estruturais}

As miopatias congênitas são genericamente definidas como miopatias primárias com início na infância, freqüentemente de natureza hereditária, lentamente progressivas, caracterizadas por presença de alterações não específicas, tais como predominância e/ou atrofia de fibras tipo 1 , associadas a lesões estruturais específicas no interior das fibras musculares. A definição da anormalidade morfológica no tecido muscular esquelético é fundamental para a identificação do tipo de miopatia congênita e sua presença em quantidade significativa em indivíduos com o mesmo quadro clínico consiste em importante aspecto diagnóstico. Portanto, a avaliação clínica, os dados genéticos e os achados morfológicos na biópsia muscular são os pontos principais no diagnóstico de uma miopatia congênita (Goebel \& Fidzianska, 1996). É importante salientar que estes marcadores morfológicos podem ser encontrados em várias outras doenças neuromusculares, mas em quantidade muito inferior, ou associados a características mais óbvias destas patologias.

Dentre as alterações estruturais no interior da fibra muscular, encontramos anormalidades de sarcômeros (Miopatia de Central Core e Mini Core), anormalidades na linha Z (Miopatia Nemalínica, Desminopatias), anormalidades nucleares (Miopatia Miotubular, Centronuclear), inclusões citoplasmáticas e anormalidades de organelas (Quadro 1). Nas miopatias sem alterações estruturais, são descritas as formas desproporção congênita de tipo de fibras, e vários tipos de atrofias de fibras tipo 1 e 2 .

Dentre as doenças neuromusculares que se manifestam desde o nascimento, iremos abordar também as distrofias musculares congênitas, que embora não sejam habitualmente classificadas no grupo das miopatias congênitas, constituem um grupo importante no diagnóstico diferencial da criança hipotônica. Daremos maior ênfase nas formas onde houve significativo progresso na localização dos genes responsáveis e caracterização da proteína. 
Tabela 2: Classificação das miopatias congênitas estruturais com padrão de herança, localização cromossômica, gene e produto protéico.

\begin{tabular}{|c|l|l|l|l|l|}
\hline & Herança & cromossomo & gene & proteína & MIM \\
\hline \multirow{2}{*}{ Central Core } & AD & $19 q 13.1$ & RYR1 & Receptor de rianodina & $\underline{117000}$ \\
\cline { 2 - 6 } & & $14 q 11.2-q 12$ & MYH7 & cadeia pesada da miosina & $\underline{160760}$ \\
\hline Mini Core & AD/AR & $?$ & & & \\
\hline \multirow{4}{*}{ Miotubular } & XR & Xq28 & MTMX & miotubularina & $\underline{\underline{310400}}$ \\
\cline { 2 - 6 } & AR & $?$ & & & $\underline{\underline{155200}}$ \\
\cline { 2 - 6 } & AD & $?$ & DNM2 & Dinamina 2 & $\underline{\underline{160150}}$ \\
\hline & AD/AD & $1 \mathrm{q} 21-23$ & NEM1-TPM3 & Tropomiosina 3 & $\underline{\underline{161800}}$ \\
\cline { 2 - 6 } & AR & $2 \mathrm{q} 21.2$ & NEM2 & nebulina & $\underline{\underline{256030}}$ \\
\cline { 2 - 6 } & AR/AD & $1 \mathrm{q}$ & & actina & $\underline{6092610}$ \\
\cline { 2 - 6 } & & & & Tropomiosina 2 & $\underline{605655}$ \\
\cline { 2 - 6 } & & & & Troponina T1 & \\
\hline
\end{tabular}

* Vainzof M. Miopatias Congênitas. In Carakushansky G: Doenças Genéticas em Pediatria. Guanabara Koogan S/A, RJ, 2001.

\subsection{Central Core (e Hipertermia Maligna)}

A Miopatia Central Core se caracteriza pela presença de "cores": lesões localizadas centralmente, ou não, no interior da fibra muscular (Dubowitz, 1985). É a forma mais comum das miopatias congênitas. Clinicamente, os pacientes com CCD apresentam fraqueza muscular neonatal com possível associação com anormalidades esqueléticas. Entretanto, alguns pacientes podem ser clinicamente normais e somente serem detectados através de biópsia muscular por causa de estudos familiares (Akiyama e Nonaka, 1966). Os cores são lesões dos sarcômeros e podem ser divididos em estruturados e não estruturados. Geralmente, encontra-se o mesmo padrão de cores dentro de uma mesma família. Na região dos cores, há ausência de mitocôndrias, como pode ser demonstrado pelas reações da NADH-tetrazolium-redutase e citocromo c oxidase. (fig. 1). A patogenia dos cores na CCD humana ainda não foi totalmente elucidada.

Numerosos trabalhos enfatizam a associação de CCD com susceptibilidade a Hipertermia Maligna (HM). A Hipertermia Maligna é uma doença do músculo esquelético, potencialmente letal, onde o indivíduo afetado é susceptível a anestésicos voláteis e relaxantes musculares que despolarizam o músculo. Quando submetido à cirurgia, e ao agente anestésico desencadeador, o indivíduos susceptível sofre um ataque fulminante de HM que é tipicamente composto por hipercontração dos músculos, acidose metabólica e respiratória, taquicardia, rabdomiólise, elevação muito grande da temperatura corporal e óbito, se não tratado rapidamente com o relaxante muscular pos-sináptico dantrolene. Embora HM possa ser associada com um grande número de doenças neuromusculares, sua ocorrência em CCD é mais freqüente (Wedel, 1992). Portanto, todo paciente suspeito ou comprovadamente afetado por CCD deve ser investigado para susceptibilidade a HM. A CCD e HM são alélicas, predominantemente de herança autossômica dominante, 
com mutações comuns ou específicas no gene RYR1, que codifica o canal de cálcio do retículo sarcoplasmático.

O gene RYR1 (em 19q12,) é composto por aproximadamente $160 \mathrm{~kb}$, contendo 106 exons. A proteína codificada forma uma elaborada estrutura tetramérica, composta por 4 sub-unidades de cerca de $560 \mathrm{kDa}$ cada, que compõem o canal de liberação de cálcio do retículo sarcoplasmático do músculo esquelético.

Até a presente data, mais de 100 mutações diferentes já foram descritas no gene RYR1 em pacientes com CCD e HM (Brandt et al., 1999). Entretanto a freqüência de cada uma das mutações é baixa, entre $2 \%$ e $10 \%$ dos casos, sendo algumas delas encontradas em famílias únicas ou em uma população específica. Além disso, uma significante heterogeneidade genética ocorre na HM, sendo que mutações no gene RYR1 correspondem a cerca de $50 \%$ a $70 \%$ dos casos, o que torna a triagem de mutações extremamente demorada e custosa.

Várias triagens foram realizadas em parte da população brasileira com HM e CCD. Não foram identificadas mutações no gene CACNL1A3 e identificamos uma mutação no gene RYR1 em uma família com HM (Viviane Muniz - TCC). Um levantamento recente de todas as mutações descritas no gene RYR1, tanto em pacientes com CCD como HM, mostrou que cerca de 90\% delas se concentram em 18 dos 106 exons do gene. Por isso, estamos estabelecendo uma metodologia para a triagem inicial destas mutações nos pacientes brasileiros (Lucas Maia, projeto de IC).

O exame atualmente disponível para a detecção da susceptibilidade à HM é o teste de contratura in vitro (IVCT), feito em amostras de biópsias musculares que são expostas ao halotano e cafeína. De acordo com o teste, os indivíduos podem ser susceptíveis (MHS), normais (MHN) ou equivocados (MHE), quando respondem ou ao halotano ou à cafeína somente. Nos estudamos uma família com HM, na qual 10 indivíduos apresentaram resultado positivo para o IVCT. Entretanto, o estudo de DNA identificou a mutação Arg614Cys no gene RYR1 em somente 3 deles. Através de estudos de ligação, utilizando quatro marcadores do cromossomo 19, verificamos se a região do cromossomo 19 englobando a mutação estava segregando com o teste IVCT. Verificamos que os 7 indivíduos susceptíveis à HM através do teste IVCT (1 MHS e $6 \mathrm{MHE}$ ), porém sem a mutação descrita na família apresentaram haplótipos diferentes dos observados nos 3 indivíduos com a mutação. Estes resultados sugeriram que outros fatores podem interferir com o resultado do teste de contratura in vitro. (Muniz e col., 2003).

Recentemente, identificou-se na região C-terminal do gene RYR1 uma grande freqüência de mutações em pacientes com CCD. A análise desta região (exons 94-101) foi realizada em 9 famílias brasileiras com CCD e mutações foram encontradas em pelo menos 5 delas (Patrícia Kossugue, TCC, 2004). Algumas destas mutações estão sendo descritas pela primeira vez e outras estão sendo encontradas em homozigose. Este fato é de significante importância para uma doença com um padrão clássico de herança autossômica dominante. Portanto uma primeira publicação esta sendo redigida, descrevendo uma possível maior freqüência de famílias com CCD e padrão de herança autossômica recessiva na população brasileira (Kossugue e col., 2006). O trabalho da Patrícia foi apresentado em diversos congressos nacionais e internacionais, e mereceu menção honrosa em simpósio de iniciação cientifica da USP.

Vainzof M, Muniz VP, Tsanaclis AM, Silva HCA, Rusticci MS. Does the A3333G mutation in the CACNL1A3 gene detected in malignant hypertermia also occur in Central Core Disease? Genetic Testing, 4(4): 383-6, 2000.

Viviane Palhares Muniz : TCC - curso básico de biomédicas, UNISA. Monografia: Estudo do gene RYR1 na Hipertermia Maligna e na Miopatia de Central Core. Dez/2002. 
Muniz VP, Silva HCA, Tsanaclis AMC, Rusticci MS, Zatz M, Vainzof M. Miopatia de Central Core e Hipertermia Maligna: triagem de mutações no gene RYR1 e CACLN1A3. XIX Congresso Brasileiro de Neurologia e II Encontro Luso Brasileiro de Neurologia. Salvador, Bahia, 7-12/10/00

* Muniz VP, Silva HCA, Tsanaclis AMC, Vainzof M. Screening for mutations in the RYR1 gene in families with malignant hyperthermia. J. Molec. Neurosc. 21(1):35-42. 2003.

Patrícia Mayumi Kossugue: Trabalho de Conclusão de IC. Curso de Ciencias Biológicas, USP. Projeto: Estudos de Ligação e triagem de mutações no gene RYR1 em famílias com pacientes afetados por miopatia de Central Core. novembro/2004. Bolsa: FAPESP.

* Kossugue PM, Paim JFO, Silva HC, Pavanello RCM, Gurgel Giannetti J,Zatz M, Vainzof M, Central Core disease due to recessive mutations in RYR1 gene: is it more common than described? Muscle and Nerve (em revisão), 2006

\subsection{Miotubular e Centronuclear}

A miopatia miotubular (MTM) é uma afecção grave, que se caracteriza por uma hipotonia neonatal marcante, acompanhada de insuficiência respiratória que requer intubação e respiração artificial contínua. O quadro grave leva à óbito, logo após o nascimento, ou algumas semanas depois (geralmente durante o primeiro ano de vida) (Wallgren-Pettersson \& Clarke, 1998). Esta forma é de herança ligada ao cromossomo $X$ e portanto afeta somente crianças do sexo masculino. Mutações no gene MTM1, que codifica a proteína miotubularina, são responsáveis por esta patologia (Laporte et al. 1996).

Uma segunda forma de miopatia, a Miopatia Centronuclear (CNM), também é congênita porém de evolução mais branda, e afeta indivíduos de ambos os sexos. Ela compreende a forma infantil, de herança autossômica dominante ou recessiva, ou também formas de início mais tardio, ou de adultos. As características clínicas são a presença de ptose palpebral ou oftalmoplegia e fraqueza facial associada a fraqueza dos membros generalizada ou proximal. As características anatomopatológicas são predominância e hipotrofia de fibras tipo 1, com núcleos centrais em freqüência variada, que tendem a aumentar com a idade. Ate muito recentemente, não haviam genes identificados como responsáveis por estas formas de CNM (Wallgren-Pettersson \& Clarke, 1998). No início deste ano, mutações no gene da dinamina 2 foram associadas a forma do adulto, de herança autossômica dominante (Bouin e col, 2006).

O gene MTM1 codifica um transcrito de $3.9 \mathrm{~kb}$ que é expresso em todos os tecidos humanos e outro de $2.4 \mathrm{~kb}$, expresso somente em músculo esquelético e testículos. O gene MTM1 é composto por 15 exons, que codificam uma proteína de 206 aminoácidos, a miotubularina, que possui um motivo protéico altamente conservado, um sítio ativo presente em todas as proteínas tirosina fosfatases (PTP), no exon 11. Visto que proteínas com motivos PTP são importantes componentes de muitas vias envolvidas no controle de vários processos celulares básicos tais como crescimento e diferenciação, acredita-se que a miotubularina possa desenvolver papel importante na regulação da maturação da fibra muscular (Tanner e col., 1999).

Mais de 60 mutações já foram identificados no gene MTM1 em pacientes com miopatia miotubular. Os dados mais atuais compreendem a triagem de mutações feitas pelo consórcio de 3 grupos de investigadores, liderados pela Dra. Laporte (Laporte e cols. 1997) que identificaram mutações no gene MTM1 em 55 dentre 85 pacientes (65\%). Mais de $50 \%$ das mutações ocorrem no domínio TPT.

Nós utilizamos as recomendações do Consórcio Mundial de Miopatia Miotubular, e estudamos os 15 exons do gene MTM1, iniciando com os exons 8, 9, 4, 11, 12 e 5 que são os mais freqüentemente mutados e abrangem cerca de dois terços das mutações já caracterizadas. Depois, foram incluídos os exons 14, 6, 3, 7 e 10, que abrangem aproximadamente um terço das mutações. Por fim os exons 1, 2, 15 quando não se 
observa alterações dentro dos exons mais freqüentes. Em um paciente com quadro grave da doença, identificamos uma deleção de $3 \mathrm{pb}$, que exclui o resíduo glutamina na posição 48 , no domínio altamente consrvado GRAM. A mutação foi herdada da mãe portadora (Lima e col., 2002). A análise da proteína miotubularina por imunohistoquímica mostrou que a proteína estava presente nas fibras musculares do pacientes. Considerando-se que esta forma de miopatia é geralmente causada por mutações que levam a ausência total da proteína no músculo, os achados no nosso paciente sugerem que algumas mutações em fase são compatíveis com a retenção da proteína, mas com graves alterações funcionais, uma vez que o paciente sobreviveu apenas um ano. (Lima e col., 2003).

Lima HP, Gouveia TLF, Zatz M, Vainzof M. Triagem de mutações no gene MTM na miopatia miotubular. 48o Congresso Brasileiro de Genética, Águas de Lindóia, 17-20 de setembro de 2002.

* Lima HP, Gouveia TLF, Tsanaclis AMC, Gurgel-Gianneti J, Silva HCA, Zatz M, Laporte J, Vainzof M. Myotubularin protein and DNA analysise in myotubular myopathy. 8th International Congress of the World Muscle Society, Szeged, September 3-6, 2003. Neuromuscl. Disord. 13: 628, 2003.

\section{Miopatia Centronuclear}

Até a presente data, nenhum gene responsável pelas formas $A D$ ou AR de miopatia centronuclear foi ainda identificado. Sugere-se que mutações responsáveis pela miopatia centronuclear possam ocorrer em um ou mais dos oito genes análogos autossômicos do gene da miotubularina (Carpenter, 2002).

As proteínas fosfatases são enzimas de estrutura e funcionamento muito diverso e segundo suas propriedades são divididas em três grupos. Um deles é o grupo das proteínas Tirosina fosfatases (PTPs), que têm um importante papel em vias de transdução de sinal que levam ao crescimento e diferenciação celular em diversos sistemas. Mutações em genes codificantes de PTPs já foram relacionados a diversas doenças congênitas humanas, assim como doenças de imunodeficiência e câncer. A família Ptpl possue pelo menos três genes integrantes, o primeiro deles, o PTPLA, foi mapeado no genoma humano por hibridação in situ no cromossomo 10, especificamente na região 10p13-p14. O gene para PTPLA se expressa em alguns órgãos como fígado, rins e testículos, porém sua expressão é maior nos músculos esqueléticos, sendo o músculo cardíaco aquele que apresenta a expressão mais acentuada do gene. Estes dados sugerem que a atividade de fosfatase desta proteína possui um papel importante na miogênese e na cardiogênese (Uwanogho, 1999; $\mathrm{Li}, 2000)$.

Recentemente uma linhagem de cães da raça labrador foi estabelecida contendo 20 indivíduos normais e 20 afetados por uma miopatia congênita com características clínicas e histopatológicas muito semelhantes àquelas observadas na miopatia centronuclear em humanos. O padrão de herança na linhagem é autossômico recessivo. Os estudos de ligação localizaram o gene responsável no cromossomo 2 canino em uma região que é ortóloga à região 10p em humanos (Tiret et al, 2003).

Estudos de ligação utilizando 5 marcadores polimórficos associados ao gene PTPLA foram realizados em 27 indivíduos, pertencentes a 3 famílias brasileiras com miopatia Centronuclear com padrão de herança autossômica dominante. Foi possível excluir a ligação em duas delas, e a terceira não permitiu a confirmação, ou exclusão. Foi então realizada triagem de mutações nos 7 exons do gene PTPLA incluinido na análise 14 pacientes com CNM que eram casos isolados na familia. Não foram identificadas alterações com caráter patogênico na seqüência dos exons deste gene em nenhum dos pacientes avaliados (Fernando Z. Velloso - TCC- 2004). Este experimento, no entanto, identificou no exon 6 deste gene e no intron 
subseqüente duas mutações que após sequenciamento foram identificadas como Polimorfismos já descritos na literatura. Estes Polimorfismos (679 C>T e 785 -3737 C>G respectivamente) foram encontrados ligados e se apresentaram com uma freqüência de $26.3 \%$ na amostra estudada (Velloso e col., 2005). O gene PTPLA parece portanto não estar associado a estas formas de CNM.

De fato, no final de 2005, foi identificado um novo gene envolvido com a miopatia Centronuclear. Mutações recorrentes foram identificadas no gene da dinamina 2 em diversas famílias francesas (Bitoun col., 2005). O estudo deste gene foi iniciado recentemente em nosso laboratório, e a análise preliminar de 4 exons em 5 famílias brasileiras já identificou 2 mutações recorrentes em 3 delas (Karen Sell, projeto de IC, 2006).

\footnotetext{
Fernando Janczur Velloso: Aluno do Curso de Ciencias Biológicas, USP. Projeto: Triagem de mutações na miopatia congenita centronuclear. Iniciação cientifica formal. Apresentado em novembro/2004. Bolsa PIBIC.

* Velloso FJ, Yamamoto LU, Zatz M, Chimelli LMC, Kashiwagi F, Vainzof M,. Study of the PTPLA gene in Centronuclear myopathy. 10th International Congress of the World Muscle Society, Iguassu Falls, Brazil, September 28 to October 1 , 2005
}

Karen Sell. Aluna do curso de Farmácia-Bioquimica, da USP. Projeto: Estudo do gene dinamina 2 em pacientes com miopatia centronuclear. Início: 24/10/05. Bolsa Pibic

\subsection{Nemalinica}

A miopatia nemalínica é uma doença muscular caracterizada por hipotonia e fraqueza muscular de predomínio proximal associada a deformidades esqueléticas e dismorfismo facial (facie alongada, boca em carpa, hipomimia). Pode apresentar herança autossômica dominante ou recessiva, e sua incidência tem sido estimada em 2 por 100.000 nascimentos vivos (North et al., 1997). Na biópsia muscular, observa-se um predomínio significativo de fibras tipo 1, e a presença no interior da fibra muscular dos "rods", ou estruturas em bastões, é o marcador patológico desta doença (Dubowitz, 1985). Os "rods", evidenciados na coloração histológica de Gomory modificado, são compostos por aglomerados de proteínas da banda Z do sarcômeros. A proporção de fibras contendo rods, bem como a quantidade de rods por fibra pode variar entre os indivíduos, entre os diferentes músculos e com a evolução da doença (Wallgreen-Pettersson\& Laing, 1998).

$\mathrm{O}$ defeito primário da MN consiste de mutações em pelo menos 5 diferentes genes: alfa-tropomiosina 3 (1q22-23), nebulina (2q21.1-q22), actina (1q42), tropomiosina 2 (9p13) e troponina T1 (19q13.4). O efeito destas mutações na expressão das proteínas musculares e o mecanismo de formação dos rods não estão ainda definidos.

O gene da nebulina é o maior gene humano, e a sua identificação, clonagem e triagem de mutações em pacientes com NM somente é realizado pelo grupo da Dra Carina Walgreen-Pettersson, coordenadora do consórcio Internacional de Miopatia Nemalínica, na Finlândia (Walgreen-Pettersson e col., 1994). Por causa da dificuldade de se estudar este gene, mutações foram encontradas em cerca de $25 \%$ das famílias com NM, triando-se cerca de $25 \%$ a $50 \%$ dos 183 exons do gene (Walgreen-Pettersson e col., 1994). Os pacientes com mutações no gene da nebulina apresentam mais freqüentemente herança AR, e o quadro típico de NM.

A segunda forma mais freqüente, cerca de $15 \%$ dos casos, ocorre devido a mutações no gene da alfaactina, observando se tanto um padrão recessivo como dominante e quadro clínico mais grave. Os outros genes mutados foram encontrados em famílias esporádicas. 
Nós realizamos triagem de mutações nos genes TPM3 e actina nos pacientes brasileiros com MN (Sharshat e col.,2001; Lima e col., 2003). Os pacientes brasileiros foram também cadastrados no Consórcio Internacional de Miopatia Nemalínica, contribuindo para o estudo internacional desta forma de miopatia (Wallgren-Pettersson e col., 2004).

A nebulina é uma proteína gigante (600-800 kDa) que se localiza ao longo de todo o filamento fino do sarcômero do músculo esquelético e corresponde a cerca de 3-4\% do total de proteínas miofibrilares. Como a maioria das proteínas miofibrilares, a nebulina se expressa de forma diferencial nos diversos tecidos musculares e de acordo com estágios de desenvolvimento. Além disso, o tamanho da nebulina se correlaciona com o tamanho do filamento fino nos diferentes músculos esqueléticos. Portanto, acredita-se que ela funcione como uma régua molecular que regula o tamanho do filamento fino.

Um extenso estudo molecular, histológico e protéico foi realizado nos pacientes brasileiros com miopatia nemalínica (Juliana Gurgel-Gianneti, Tese de Doutorado, 2001). Foi avaliada a expressão da proteína nebulina no tecido muscular de 13 pacientes com diagnóstico de MN (10 com a forma típica , 2 com a forma congênita grave e $1 \mathrm{com}$ a forma juvenil), usando anticorpos contra 3 domínios diferentes desta proteína e correlacionamos estes dados com a variabilidade clínica. A análise quantitativa e qualitativa da nebulina no tecido muscular não mostrou ausência desta proteína em nenhum dos pacientes. Considerando a estrutura dos rods algumas diferenças foram observadas: a maioria dos rods subsarcolemais grandes mostraram-se negativos com o anticorpo nebulina N2 enquanto sua estrutura mostrou-se indistinta do resto da fibra com os anticorpos nebulina 101-102 e 176-181. Os rods difusos não foram evidenciados nas reações com nenhum dos três anticorpos anti-nebulina. Foi detectada mutação no gene da nebulina em duas irmãs: deleção de 2 bp no exon 173, que leva a um stop codon 6154. A análise da nebulina nestas duas irmãs mostrou um padrão discordante de marcação dos rods. Nossos resultados sugerem que a presença ou ausência de epítopos específicos da nebulina nas estruturas dos rods é variável e pode estar relacionada com o seu grau de organização (Gurgel et al., 2001). Interessantemente, observamos deficiência do domínio C-terminal da nebulina em uma das pacientes, de 14 anos, com quadro clínico da forma clássica de NM. Na biópsia muscular observou-se um predomínio total de fibras tipo 1 associados a presença de rods pequenos e difusos, em $100 \%$ das fibras (Gurgel et al., 2002).

Foi também realizado estudo para avaliar possíveis alterações no padrão de distribuição dos rods no interior das fibras musculares e na diferenciação de tipo de fibras, com a evolução da doença, em pacientes com miopatia nemalínica. A análise compreendeu o estudo histológico/histoquímico e imunohistoquímico em tecido muscular de 15 pacientes com MN. A análise evolutiva foi feita através do estudo de biópsias de dois pacientes que foram submetidos a uma segunda biópsia após 10 e 13 anos, e de duas irmãs de diferentes idades, com mutação no gene da nebulina. Para o estudo imunohistoquímico com dupla marcação, utilizouse os anticorpos para a alfa-actinina 3 e miosina rápida. Determinou-se o padrão predominante de distribuição dos rods e a porcentagem de fibras tipo 1 e tipo 2. Os resultados encontrados nas biópsias realizadas em diferentes idades mostraram uma tendência dos rods difusos se redistribuírem na região subsarcolemal. Observou-se maior proporção de fibras tipo 2 em pacientes mais jovens e detectou-se a presença de isoformas de proteínas expressas normalmente em fibras tipo 2 em fibras tipo 1 . Uma maior proporção de fibras tipo 2 foi observada na irmã mais nova, dentre as duas com mutação no gene da nebulina. Concluímos que o quadro histopatológico da MN não é estático. Com a evolução da doença parece ocorrer uma reorganização dos rods na região sub-sarcolemal e uma transformação de fibras tipo 2 em fibras tipo 1 (Gurgel et al., 2003). 
A análise molecular do gene TPM3 realizada nestes mesmos pacientes identificou padrão de migração alterado em gel de SSCP em uma paciente. O seqüenciamento do fragmento alterado confirmou uma mutação de sentido trocado $\mathrm{A} 150 \mathrm{C}$, que provoca a substituição $\mathrm{K} 92 \mathrm{~T}$, no codon 31 do exon 1 do gene TPM3. Para verificar se esta mutação é a causa da doença, foi avaliada a sua presença e freqüência em 100 indivíduos normais da população brasileira, e fragmento semelhante foi encontrada em 6 indivíduos adicionais. Como a primeira mutação patogênica encontrada neste gene está presente exatamente no exon 1 , este fragmento foi intensamente pesquisado em diversos outros estudos internacionais. Nenhum polimorfismo adicional foi descrito. Portanto, esta alteração foi considerada um polimorfismo raro, presente na população brasileira (Sheila Charchat, TCC, 2001)

Tese de Doutorado: Juliana Gurgel-Giannetti. Projeto intitulado “Miopatia Nemalínica: Estudo clínico, imunohistoquimico e genetico". Departamento de Neurologia, Faculdade de Medicina, USP. Defesa de tese de doutorado em 12/12/2001.

* Gurgel-Gianetti J, Umbertina Reed, Sueli K. Marie, Mary Carvalho, Edmar Zanoteli, Moacir A.T. Fireman, Acary S.B. Oliveira, Mayana Zatz, Mariz Vainzof. Nebulin Expression in patients with Nemaline Myopathy. Neuromusc. Disord. 11(2):154-62, 2001.

* Gurgel-Giannetti J, Canovas M, Marie-Louise Bang, Umbertina Reed, Suely K Marie, Mayana Zatz, Siegfried Labeit, Mariz Vainzof. The lack of the C-terminal domain of nebulin in a patients with nemaline myopathy. Muscle\&Nerve 25: 74752, 2002.

Gurgel-Giannetti J, Reed U, Zanoteli E, Werneck LC, Beggs A, Fireman MAT, Oliveira ACB, Zatz M, Vainzof M. Rod distribution and muscle fibers type modification in the progression of nemaline myopathy . J. child neurol, 18 (3): 235 40, 2003.

Monografia de conclusão de curso: Sheila Cherchat. Curso de Farmácia-Bioquímica, PUC-RS. Monografia: Caracterização de uma mutação patogênica no gene TPM3 em paciente com miopatia nemalínica. Julho/2001.

* Charchat S, Gurgel-Giannetti J, Starling A, Zatz M, Vainzof M. Estudo da frequencia da nova mutação A150C no gene TPM3, em miopatia nemalínica e na população brasileira. . SIINCUSP, Ribeirão Preto, 7-8 de novembro de 2001.

Lima BL, Gurgel-Gianneti J; Zanoteli E, Vainzof M. Estudo de mutações no gene alfa actina em pacientes com miopatia nemalínica. 49o Congresso Nacional de Genética. Águas de Lindóia, SP, 16-19 de setembro de 2003.

C. Wallgren-Pettersson1*, MD, PhD, K. Pelin1**, PhD, K. J. Nowak2, PhD, F. Muntoni3 MD, PhD, N. B. Romero4 MD, PhD, H. H. Goebel5 MD, PhD, K.N. North6 MD, PhD, A. H. Beggs7, PhD, N.G. Laing2, PhD, and the ENMC International Consortium on Nemaline Myopathy. Genotype-phenotype correlations in nemaline myopathy caused by mutations in nebulin and $\alpha$-actin. Neurom. Disrod 14(8-9):461-70, 2004

\subsection{Distrofias Musculares Congênitas}

As distrofias musculares congênitas (CMD) são um grupo de doenças musculares caracterizado pela presença de fraqueza muscular difusa no período neonatal, grau variável de contraturas nas articulações e possível associação com anormalidades no sistema nervoso central ou olhos. A biópsia muscular invariavelmente apresenta alterações histopatológicas distróficas. A evolução é geralmente lenta ou não progressiva e, eventualmente, pode ocorrer melhora funcional (Dubowitz 1985).

Nas últimas duas décadas, os pacientes com diferentes variantes de CMD foram organizados em categorias específicas, classificados com base nas principais características clínicas, e mais atualmente, com os avanços nos estudos moleculares, também em função dos defeitos genéticos e bioquímicos primários. Até a presente data, foram identificados dez genes que causam formas especificas de CMD. Entretanto, acreditase em uma heterogeneidade maior (Muntoni, 2004).

Atualmente, a classificação sugerida pelo consórcio internacional de CMD reconhece as seguintes categorias da doença: 
1. Genes codificadores das proteínas estruturais da membrana basal ou matriz extracelular das fibras musculares esqueléticas Incluem: genes do colágeno VI, cadeia alfa-2 laminina e alfa-7 integrina.

2. Genes codificadores de glicosiltransferase sugeridos e demonstrados que afetam a glicosilação da $\alpha$-distroglicana, uma proteína de membrana externa da membrana basal. Genes que são incluídos: POMT1; POMGnT1, fukutin; fukutin-related protein (FKRP); Large.

3. Selenoproteína 1, que codifica uma proteína do retículo endotelial de função desconhecida.

Tabela 3 - Formas reconhecidas geneticamente de CMD

\begin{tabular}{|c|c|c|c|c|c|c|}
\hline $\begin{array}{l}\text { Categoria } \\
\text { Proteína }\end{array}$ & $\begin{array}{c}\text { Forma de } \\
\text { CMD }\end{array}$ & Doença & Gene & Localiz. & proteína & MIM \\
\hline \multirow{5}{*}{$\begin{array}{c}\text { Matriz } \\
\text { extracelular }\end{array}$} & MDC1A & Merosina-negativa & LAMA2 & $6 q 2$ & Laminina $\alpha 2$ & $\underline{607855}$ \\
\hline & UCMD1 & \multirow{3}{*}{$\begin{array}{l}\text { CMD-Síndrome de } \\
\text { Ullrich } \\
(1,2,3)\end{array}$} & COL6A1 & $21 q 2$ & Colágeno VI & $\begin{array}{r}254090 \\
120220 \\
\end{array}$ \\
\hline & UCMD2 & & COL6A2 & $21 q 2$ & Colágeno VI & $\underline{120240}$ \\
\hline & UCMD3 & & COL6A3 & $2 q 3$ & Colágeno VI & 120250 \\
\hline & & Def. $\alpha 7$ - Integrina & ITGA7 & $12 q$ & $\alpha 7$-integrina & $\underline{600536}$ \\
\hline $\begin{array}{c}\text { Retículo } \\
\text { endoplasmático }\end{array}$ & RSMD1 & $\begin{array}{l}\text { Síndrome da espinha } \\
\text { rígida }\end{array}$ & SEPN1 & $1 \mathrm{p} 3$ & Selenoproteína N,1 & $\underline{602771}$ \\
\hline \multirow{6}{*}{$\begin{array}{l}\text { Glicosiltransferase } \\
\text { (variantes c/ } \\
\text { glicosilação } \\
\text { anormal da } \alpha- \\
\text { distroglicana) }\end{array}$} & WWS & $\begin{array}{l}\text { Síndrome de Walker } \\
\text { Warburg }\end{array}$ & POMT1 & $9 q 34$ & $\begin{array}{c}\text { Proteína O- } \\
\text { manosiltransfe-rase }\end{array}$ & $\underline{236670}$ \\
\hline & MEB & "Muscle eye-brain" & POMGnT1 & $1 \mathrm{p} 3$ & $\begin{array}{l}\text { O-linked manose beta } \\
1,2-\mathrm{N} \text {-acetil } \\
\text { glicosaminoltransferase }\end{array}$ & $\underline{253280}$ \\
\hline & FCMD & Fukuyama & FCMD & $9 q 3$ & fukutina & 253800 \\
\hline & MCD1B & $\begin{array}{l}\text { CMD+ (deficiência } \\
\text { secundária de } \\
\text { merosina) }\end{array}$ & $?$ & $1 q 4$ & $?$ & $\underline{604801}$ \\
\hline & MCD1C & $\begin{array}{l}\text { CMD+ (deficiência } \\
\text { secundária de } \\
\text { merosina) }\end{array}$ & FKRP & $19 q 13$ & $\begin{array}{l}\text { "Fukutin-related } \\
\text { protein" }\end{array}$ & $\underline{606612}$ \\
\hline & MDC1D & $\begin{array}{c}\text { CMD c/ retardo } \\
\text { mental e pachygyria }\end{array}$ & LARGE & $22 q$ & Large & $\underline{608840}$ \\
\hline
\end{tabular}

\section{I - DEFEITOS NA MATRIZ EXTRACELULAR}

* A forma pura ou clássica caracteriza-se pela presença de fraqueza muscular com hipotonia ou artrogripose, alterações histológicas do tipo distróficas, com aumento significativo de tecido conjuntivo e adiposo, níveis normais ou ligeiramente elevados da enzima sérica $\mathrm{CK}$, inteligência geralmente normal e uma variabilidade clínica significativa (Echenne e cols., 1986; Krigsman e cols., 1980; Topaloglu e cols., 1991; Reed e cols., 1996).

\section{1-) MDC1A}

Esta forma é responsável por cerca de $50 \%$ dos casos classificados como forma clássica de CMD, e é causada por mutações em um gene mapeado em 6q2 (Hillair e cols., 1994). Em 1994, Tomé e cols. identificaram a ausência da proteína merosina ou laminina $\alpha-2$ como a responsável pela patogênese da doença (MDC1A). 
Clinicamente, os pacientes merosina-negativos apresentam um fenótipo mais grave e a maioria dos pacientes é incapaz de adquirir marcha independente. Esta forma também é associada com a presença de alterações na substância branca do encéfalo, em exames de neuroimagem. Entretanto, os sinais de imagem não se correlacionam com sinais clínicos de comprometimento de SNC e a natureza e o significado destas alterações aguardam maiores estudos.

O gene Lama-2 é composto por 260 kb organizado em 64 exons e o cDNA tem cerca de 9,5 kb. Não foi identificado um "hot spot" de mutações neste gene. Entretanto, ocorre um efeito fundador para algumas das mutações encontradas (Guicheney e cols., 1998). A maioria das mutações leva a formação de uma proteína truncada em um dos domínios que formam o braço curto da cadeia $\alpha-2$ da laminina. O RNAm formado é provavelmente muito instável e, mesmo em caso de formação do polipeptídio, acredita-se que este não teria o domínio globular G (C-terminal) e os domínios I e II do braço longo da cadeia e, portanto, não poderia participar da formação do heterodímero normal da laminina (Tomé e cols., 1998).

O estudo de mutações no gene Lama-2 mostrou grande heterogeneidade e as primeiras mutações neste gene foram descritas em 1995 por Helbling-Leclerc e cols. Entretanto, pouco estudo adicional tem sido realizado em função do grande tamanho desse gene, cuja triagem de mutações ao longo de seus 64 exons torna a análise muito trabalhosa e dispendiosa. Neste sentido, um estudo preliminar de polimorfismos ou microssatélites pode orientar a análise, sugerindo-se que em uma dada família o fenótipo da distrofia é devido a mutações no gene loco Lama-2.

A laminina 2 é a principal proteína da matriz extracelular na membrana basal da fibra muscular. Forma um heterotrímero em forma de cruz com as cadeias $\alpha 2, \beta 1$ e $\gamma 1$. Liga-se ao citoesqueleto sub-sarcolemal por um grande complexo de glicoproteínas associadas à distrofina. O bom funcionamento do complexo seria responsável por um correto mecanismo de contração muscular (Ervasti \& Campbell, 1993). Portanto, assim como a deficiência de distrofina leva às distrofias de Duchenne e Becker, alterações nas proteínas do complexo DAG levam às distrofias musculares tipo Cinturas (LGMD), e a deficiência da proteína merosina leva a uma das formas de distrofia muscular congênita.

A cadeia $\alpha 2$ da laminina, originalmente com $400 \mathrm{kDa}$, sofre uma clivagem pós-tradução originando os fragmentos de $80 \mathrm{kDa}$ e $300 \mathrm{kDa}$. Cerca de $95 \%$ dos pacientes com mutações no gene em $6 \mathrm{q}$ apresentam deficiência total da proteína, enquanto que os restantes, $5 \%$, apresentam deficiências parciais relacionadas a mutações de sentido trocado ou as deleções que não alteram o quadro de leitura (Hayashi e cols., 1997; Allamand e cols., 1997).

Desde a identificação do loco responsável pela CMD merosina-deficiente em 6q2 (Hillaire e cols., 1994) e da simultânea descoberta do gene responsável pela síntese da cadeia $\alpha-2$ da laminina em 6q2223 (Vuolteenaho e cols., 1994), surgiu o interesse de se estudar as correlações genótipo/fenótipo da CMD. Estudos na população brasileira mostraram uma proporção semelhante de pacientes com MDC1A através da análise da proteína merosina no músculo (Vainzof e col., 1995; Reed e col. 1996). Atualmente, este diagnóstico é rotineiramente realizado em biópsias do músculo esquelético, em pacientes candidatos. Estudos complementares identificaram pacientes atípicos com deficiência parcial de $\alpha 2$-laminina na população brasileira (Reed e col., 2000). A caracterização das mutações em nossos pacientes com deficiência de a2-laminina, tanto com quadro grave, como mais benigno faz parte do projeto de pósdoutoramento da Dra. Lydia Yamamoto (FAPESP). 
A laminina 2 está presente também nas células de Schwann, trofoblasto e membrana basal de queratócitos da epiderme, o que permite o seu estudo em tecidos de obtenção mais fácil, como biópsia de pele, e a realização de diagnóstico pré-natal. O primeiro teste pré-natal da América do Sul foi implantado em nosso laboratório, incluindo estudos de ligação do loco LAMA2 e estudos protéicos em biópsias de vilosidades coriônicas, e possibilitou a identificação de um feto normal, confirmado após o nascimento (Yamamoto e col., 2004). A importância deste teste para o aconselhamento genético das famílias, e o fato de apenas alguns centros internacionais terem experiência da área, nos levou a sugerir um compilamento internacional de todos os diagnósticos pré-natais, realizados no mundo todo, nos últimos 10 anos, para avaliar o grau de confiabilidade deste tipo de diagnóstico. A análise de mais de 100 diagnósticos prénatais, realizados nos 5 principais Centros de Neuromuscular da Europa mostrou que não houve casos de teste falsos falsos negativos, ou falsos positivos, com 100\% de reprodutibilidade (Vainzof e col., 2005).

A deficiência parcial da proteína tem sido encontrada em pacientes com quadro clínico mais benigno (Tomé et al., 1994; Vainzof et al., 1995; Allamand et al., 1997). Entretanto, estudos recentes identificaram pacientes com deficiência parcial de merosina que não apresentavam mutações no gene LAMA2, sugerindo um efeito secundário (Topaloglu et al., 1998).

\section{* Formas Merosina-positivas}

O espectro de variabilidade clínica e molecular das distrofias musculares congênitas tem se ampliado. Estudos têm mostrado que mutações de sentido trocado e pequenas deleções no gene Lama-2, que não alteram o quadro de leitura, levam à formação de uma proteína truncada e deficiência parcial de merosina no músculo (Guicheney e cols., 1998). Normalmente, nos casos com deficiência parcial de merosina, o quadro clínico é menos grave, o início pode ser mais tardio e a criança chega a deambular. Além disso, estudos imunohistoquímicos têm mostrado um padrão de deficiência parcial de merosina em pacientes que apresentam quadro clínico mais benigno, compatível com a distrofia muscular tipo Cinturas (Brockington e cols., 2000). Desta forma, observa-se cada vez mais uma sobreposição das características clínicas e histopatológicas entre as formas de distrofias musculares congênitas e outras formas de distrofias musculares, principalmente as de início precoce, como algumas formas de distrofias musculares das Cinturas Limb-girdle muscular dystrophy, LGMD.

Dada esta grande variabilidade clinica e histopatológica observada nos pacientes MDC-merosinapositivos, o diagnóstico diferencial entre as diversas formas é geralmente difícil. Neste sentido, a descoberta e caracterização de novos genes envolvidos nas diferentes formas de CMD têm ajudado significativamente.

$\mathrm{Na}$ década passada, deficiência da proteína alfa-actinina 3 foi encontrada em diversos pacientes com diagnóstico clínico de distrofia muscular congênita-merosina positiva. Nós triamos para mutações neste genes um grupo de pacientes com este diagnóstico, para ver se este gene poderia estar envolvido com a patologia. Entretanto, não foram encontradas alterações significativas (Vainzof e col., 1997). Posteriormente, foi descrita uma mutação no exon 16 do gene ACTN3, a substituição C1747T, que insere um código de parada prematuro no lugar de uma arginina na posição 577 , levando à deficiência da proteína $\alpha$-actinina 3 . Esta mutação esta presente em cerca de $18 \%$ da população mundial. Contudo, a deficiência da proteína não está associada a nenhum quadro patológico, o que sugere que a $\alpha$-actinina 3 tenha função redundante no músculo e que a $\alpha$-actinina 2 compense a sua ausência nas fibras do tipo 2 (North e cols, 1999). 


\section{2-) UCMD1 A UCMD3}

Distrofia muscular de Ullrich é uma forma de CMD-merosina positiva caracterizada por contraturas proximais, rigidez da espinha e complicações respiratórias. Estudos recentes sugerem a possibilidade do envolvimento de subunidades do colágeno VI (COL2A1, CLO6A2, COL6A3) na fisiopatologia da doença, pois identificaram deficiência desta proteína no tecido muscular e em biópsia de pele de pacientes com UCMD. Mutações em genes localizados em 21q22.3 e 2q3 foram identificadas em pacientes afetados.

\section{3-) DEFICIÊNCIA DE $\alpha 7-$ INTEGRINA}

Um novo gene foi recentemente identificado em 12q13, em umas formas recessivas de CMD, cujas mutações levam a deficiência da proteína integrina- $\alpha 7 \beta 1$, um receptor de laminina. A mutação mais comum encontrada neste gene é uma deleção de 98 pb (Hayashi e cols., 1998). Clinicamente, estes pacientes apresentam hipotonia e atraso no desenvolvimento neuropsicomotor (DNPM), adquirindo marcha aos 2-3 anos. A fraqueza é proximal, a CK ligeiramente elevada, e não se observam alterações cerebrais. Alterações secundárias de $\alpha 7$-integrina foram encontradas na distrofia tipo Duchenne e Becker (elevação), Fukuyama (redução) e CMD-merosina deficiente (redução).

\section{II- DEFEITOS DE PROTEÍNAS DO RETÍCULO ENDOPLASMÁTICO}

\section{4-) RSMD1 - síndrome da espinha rígida.}

Nesta forma, a herança é autossômica recessiva e os pacientes apresentam fraqueza facial e nos membros superiores e inferiores, de grau variável, com distribuição predominantemente proximal. A capacidade de deambulação ocorre após os 2,5 anos ou nunca e não há progressão do quadro clínico. A rigidez na espinha é observada precocemente, entre os 3 e 7 anos, com limitação na flexão do pescoço e coluna. Posteriormente, os pacientes desenvolvem escoliose progressiva e contraturas diversas. O gene localizado no cromossomo 1p35-36, codifica para a selenoproteína N1.

\section{III- DEFEITOS EM PROTEÍNAS GLICOSILTRANSFERASE}

Algumas formas de MDC são caracterizadas pela presença de alterações secundárias em diversas em proteínas musculares. A proteína $\alpha$-distroglicana é fortemente glicosilada, e importante componente do complexo distrofina-glicoproteínas associadas (DGC), na membrana das fibras musculares. Alterações na glicosilaçao desta proteína foram encontradas em diversas formas de MDC. A $\alpha$-distroglicana se liga a laminina 2 muscular, completando o ancoramento do complexo na matriz extracelular do músculo (Holt e cols, 2000). Desta forma, completa-se a ligação da actina associada ao citoesqueleto com os componentes da matriz extracelular e o rompimento desse eixo está associada com formas graves de distrofia muscular .

Os defeitos de glicosilação tem sido sugeridos principalmente a partir das observações de redução 
secundária na expressão de merosina, encontrada na maioria destes pacientes. Confirmando estes achados, recentemente, evidências mostraram que ocorrem também alterações na expressão da $\alpha$-distroglicana na CMD de Fukuyama, no camundongo myd - no qual o gene LARGE glicosiltransferase é mutado - e na doença de MEB, cujo gene responsável foi também identificado como uma outra glicosiltransferase (Kobayashi e cols., 2001).

Anormalidades da via de O-glicosilação constituem portanto um novo mecanismo patogênico na distrofia muscular, abrindo novas linhas de pesquisa dentro dessas doenças. Neste sentido, os avanços na genética molecular estão possibilitando a análise direta de mutações já conhecidas no gene FKRP, bem como a triagem de novas mutações em pacientes ainda não classificados molecularmente.

Nas formas Walker-Walburg (WWB), Muscle-eye-brain (MEB), e CMD-Fukuyama (FCMD), os pacientes apresentam fraqueza muscular e padrão distrófico no músculo, além do comprometimento do SNC causando retardo mental grave e envolvimento ocular, com níveis séricos da enzima CK muito elevados (Hayashi e cols., 1993; Cormand e cols., 1999).

\section{5-) WWB}

Esta forma se caracteriza pela presença de alterações cerebrais estruturais, associadas a retardo mental. As anormalidades do SNC mais comuns são lisencefalia tipo II, paquigiria em grau variável. Malformações oculares também são comuns, mas com menor severidade das observadas na forma MEB. Mutações no gene POMT1 foram associados a esta forma. Recentemente, mutações neste gene também foram encontradas em uma forma de distrofia muscular das cinturas, com retardo mental associado (DMC2K).

\section{6-) MEB}

Os pacientes também apresentam retardo mental e envolvimento ocular e de SNC. A alteração ocular mais consistente é a miopia, que pode ser bem grave e progressiva. Além disso pode também ocorrer estrabismo, glaucoma, opacidade da lente, atrofia da retina e óptica. Nesta forma, pode também ocorrer epilepsia. A CK sérica pode ser normal no primeiro ano de vida, mas está sempre elevada nos anos posteriores.

O gene foi localizado no cromossomo 1 p32-34 por estudos de ligação e mapeamento por homozigosidade, em 8 famílias com 12 indivíduos afetados (Cormand et al.,1999). Mutações no gene POMTGNt1 são as causas da doença.

\section{7-) FCMD}

É uma forma autossômica recessiva, prevalente no Japão, responsável por cerca de $80 \%$ dos casos (Fukuyama et al., 1960). Os pacientes apresentam, alem da fraqueza muscular e do padrão distrófico no músculo, retardo mental grave, convulsões e malformações do SNC envolvendo o córtex cerebral, substância branca, tronco cerebral e cerebelo. Os níveis séricos da enzima CK são muito elevados. O gene foi mapeado em 9q31-33 (Toda et al., 1993), e codifica uma proteína de 461 aminoácidos, a Fukutina (Kobayashi et al., 1998).

Estudos de mutações no gene da Fukutina localizaram mutações de sentido trocado, sem sentido, inserção de 1pb e inserção L1 (retro-transposon de 3kb, na região 3' não traduzida do gene), que mostrou um 
efeito fundador.

Estudos da proteína fukutina mostraram que ela provavelmente tem uma localização extra-celular (Dubowitz, 1999).

\section{8-) MCD1C - FKRP}

A proteína FKRP foi identificada por causa de sua homologia com a fukutina. Esta proteína foi denominada "Fukutin-related protein" (FKRP), e tem características bioquímicas semelhantes às encontradas em muitas glicosiltransferases. Mutações no gene FKRP são responsáveis pela forma grave de MDC1C, clinicamente caracterizada pela inabilidade de andar, hipertrofia das panturrilhas, insuficiência respiratória grave na segunda década de vida, níveis elevados da CK sérica sem comprometimento cerebral e uma deficiência secundária da $\alpha 2$-laminina. Os indivíduos afetados têm uma diminuição importante da $\alpha$ distroglicana no músculo, detectada na reação imunohistoquímica e uma redução no peso molecular pela análise por Western Blot. A anormalidade de expressão da $\alpha$-distroglicana sugere ser resultante de alteração no mecanismo de glicosilação desta proteína.

Localizado no cromossomo 19q13.3, o gene FKRP tem 1488pb e é composto por quatro exons, que codificam uma proteína de 495 aminoácidos. Esta se expressa em diversos tecidos humanos com níveis elevados nos músculos esquelético e cardíaco. Estudos genéticos mostraram que mutações no gene FKRP causam tanto a forma CMD1C como uma forma de LGMD2I, mapeada previamente na mesma região cromossômica. Uma mutação prevalente, a substituição c.826C>A, foi encontrada na forma LGMD2I (Brockington e cols., 2001). Pacientes com a alteração c.826C>A têm clinicamente um fenótipo de LGMD2I menos grave, sugerindo que estas mutações causam um dano menor na proteína.

Iniciamos, portanto, o estudo de mutações neste gene em pacientes com a forma clássica de CMD com merosina positiva ou com deficiência parcial para caracterizar os pacientes brasileiros com CMD, também parte integrante do projeto de pós-doutoramento de Lydia Yamamoto (FAPESP).

Estudo preliminar realizado nos pacientes com quadro de distrofias das Cinturas com alterações secundárias da $\alpha 2$-laminina permitiu a rápida identificação de vários pacientes com mutações, sendo classificados com LGMD2I (de Paula e col., 2004). Triagem de mutações realizada em nosso grupo de pacientes com MDC (merosina positivos) mostrou uma baixa freqüência de pacientes portadores de mutações nos dois alelos do gene FKRP. Entretanto, curiosamente, observou-se uma freqüência alta de indivíduos heterozigotos entre estes pacientes levantando uma importante possibilidade deste gene ter um efeito modificador sobre outros genes (Yamamoto e col., 2004).

Foi realizado então estudo para avaliar o efeito de mutações no gene FKRP na expressão de proteínas musculares associadas a doenças neuromusculares em pacientes com distrofias musculares. Foram estudados 13 pacientes com mutações identificadas no gene FKRP e diagnóstico clínico de DMC2I. Não foram observadas anormalidades na expressão das proteínas: disferlina, $\alpha-, \beta-, \gamma-$, e $\delta$-sarcoglicanas, teletonina e colágeno VI. Entretanto, observou-se um grau variável de deficiência da $\alpha$-laminina em oito pacientes, sendo cinco portadores da mutação comum C826A. Através da análise por imunoblot, identificouse redução quantitativa da proteína distrofina em 2/13 pacientes e da proteína calpaína-3 em 4/13 pacientes. Concluímos que mutações que interferem com o mecanismo de glicosilação possivelmente alteram a importante ponte entre as proteínas contráteis no interior do músculo e a matriz extracelular, fragilizando a 
membrana e tornando a fibra muscular mais vulnerável à degeneração (Yamamoto e col., 2004).

* Vainzof M, Marie SKN, Reed UC, Schwartzman JS, Pavanello RCM, Passos-Bueno MR, Zatz M. Deficiency of Merosin in congenital muscular dystrophy associated with cerebral white matter alterations. Neuropediatrics 26:293-297, 1995.

Reed UC, Marie SK, Vainzof M,. Salum PN, Levy JA, Zatz M, diament A. Congenital muscular dystrophy with cerbral white mater hypodensity. Correlation of clinical features and merosin Brain Development 18: 53-58, 1996.

Reed UC, Marie SKN, Vainzof M, Gobbo LF, Gurgel JEP, Carvalho MS, Resende MB, Espindola A, Zatz M, Diament A. Heterogeneity of classic congenital muscular dystrophy with involvement of the central nervous system: report of five atypical cases. J Child Neurol; 15: (3) 172-178, 2000.

* Yamamoto LU, Gollop TR, Naccach NF, Pavanello RCM, Zanoteli E, Zatz M, Vainzof M. Protein and DNA analysis for the pre-natal diagnosis of $\alpha 2$-laminin-deficient congenital muscular dystrophy. Diag. Mol. Pathol. 13(3):167-71, 2004.

* Vainzof M, Richard P, Herrmann R, Jimenez-Mallebrera C, Talim B,Yamamoto LU, Ledeuil C, Mein R, Steve Abbs A, Brockington M, Romero NB, Zatz M, Topaloglu H, Voit T, Sewry C, Muntoni F, Guicheney P, Tomé FMS. Pré-natal diagnosis in laminin $\alpha 2$ chain (merosin)-deficient congenital muscular dystrophy: an international multicenter reappraisal. Neurom. Disord. 15(9-10):588-94, 2005

* Vainzof M, Costa CS, Marie SK, Moreira ES, Reed U, Passos-Bueno MR, Beggs AH, Zatz M. Deficiency of a-actinin-3 (ACTN3) occurs in different forms of muscular dystrophy. Neuropediatrics 28:1-6, 1997.

de Paula F, Vieira N, Starling A, Yamamoto LU, Lima B, Pavanello RCM, Vainzof M, Nigro V, Zatz M. Asympromatic carriers for homozygous novel mutations in the FKRP gene: the other end of the spectrum. Eur. J. Hum Genet. 11 (12): 923-930, 2003.

Yamamoto LU, Velloso FJ, Santos BHC, Kossugue PM, Fogaça LQC, Vajsar J, Paim JF, Zatz M, Vainzof M. Spectrum of mutations in the Fukutin-Related Protein gene (FKRP) in patients refered as Congenital Muscular Dystrophy. 10th International Congress of the World Muscle Society, Iguassu Falls, Brazil, September 28 to October 1, 2005. Neurom Disord 15: 706, 2005.

Yamamoto LU, Paula F, Pavanello RCM, Vieira N, Zatz M, Vainzof M. Alterações nas proteínas musculares em pacientes com mutações no gene FKRP (Fukutin-related protein). XXI Congresso Brasiliero de Neurologia, Brasília, 9-14 de outubro de 2004. Arq. Neuro-Psiq 62 (2): 13, 2004.

\section{4-) Modelos animais}

\subsection{Estudos diversos em modelos animais e triagem de novos modelos para doenças neuromusculares.}

Estudos clínicos e neurológicos em animais com fraqueza muscular têm ajudado a identificar alguns modelos animais tais como camundongos, cães e gatos, deficientes para diferentes proteínas musculares. Os estudos realizados nestes animais são cruciais para aumentar nossos conhecimentos a respeito de doenças genéticas humanas e para a investigação de terapias experimentais. A facilidade com que o genoma murino pode ser manipulado faz do camundongo uma ferramenta bastante utilizada em testes moleculares e na avaliação de complexos protéicos musculares. Dentre os modelos murinos, o camundongo $m d x$ apresenta uma mutação de ponto no gene da distrofina e ausência total da proteína no músculo, constituindo um modelo molecular e protéico para a distrofia muscular de Duchenne humana (DMD). Os camundongos $d y / d y$ e $d y^{2 J}$ são os modelos murinos para a distrofia muscular congênita com deficiência de a2-laminina, e apresentam fraqueza clinica significativa. O camundongo SJL é o modelo murino para a DMC2B, apresentando deficiência da proteína disferlina, e o camundongo LARGE é o modelo murino para defeitos de glicosilação da proteína alfa-distroglicana. Diversos outros camundongos transgênicos e knockout para as proteínas sarcoglicanas e caveolina também já foram gerados, e estão ajudando no estudo dos mecanismos de composição e funcionamento destes complexos protéicos nos animais afetados. Alem disso, 
existem modelos diversos para outras doenças genéticas, tais como o modelo porcino, com mutação no gene RYR1, que apresenta os sinais clínicos observados na crise de Hipertermia Maligna (Vainzof e col., 2005).

Devido à deficiência da proteína distrofina, como em pacientes com DMD, o músculo de camundongos $m d x$ é afetado por degeneração e necrose. Entretanto, o camundongo $m d x$ exibe um curso clínico mais brando. Além disso, a fraqueza muscular não é característica e o tempo de vida não é reduzido. Esse camundongo também apresenta um grande número de fibras revertentes (2-3\%), que passam a sintetizar novamente de forma espontânea a distrofina. Como a presença natural destas fibras dificulta a análise de terapias que visam à expressão de distrofias, outros modelos murinos de DMD foram experimentalmente induzidos.

\subsection{O cão distrófico GRMD - caracterização do padrão de degeneração em diferentes músculos e em diversas idades - avaliação da expressão da distrofina, utrofina e miostatina.}

Embora o camundongo mdx seja um bom modelo molecular, não é um bom modelo clínico, por não apresentar fraqueza muscular significativa, dificultando o seu uso na avaliação clínica da eficácia de triagens terapêuticas. Neste sentido, a identificação do modelo canino da raça Golden Retriever com deficiência de distrofina trouxe novas perspectivas, uma vez que apresenta fraqueza muscular significativa, simulando a distrofia humana. A patogênese do GRMD tem manifestação in utero com o desenvolvimento de lesões musculares linguais. Extensas necroses dos músculos dos membros, tronco e pescoço podem ser identificadas já ao nascimento. Assim como na doença humana e no modelo $m d x$, as concentrações da enzima creatino quinase sérica estão também extremamente elevadas desde o nascimento. Em seis meses, desenvolvem-se fibrose muscular e contraturas nas junções. Além disso, cães jovens com GRMD podem também morrer por falha cardíaca ou respiratória, embora alguns sobrevivam e alcancem muitos anos de vida. Diversos estudos de terapia gênica e celular estão em andamento no modelo canino da distrofia de Duchenne. A caracterização protéica foi realizada em animais de diferentes idades (Vainzof e col., 2001). Estudos posteriores da expressão da utrofina, uma proteína homologa à distrofina, mas com expressão associada a fibras em estágios iniciais de maturação, estão em andamento (Luciana Luchesi, dissertação de mestrado). Estão sendo estudadas biópsias e necrópsias musculares de animais afetados de diferentes idades, abrangendo músculos com diversos graus de degeneração, para avaliar o nível de expressão da utrofina, bem como o seu padrão de distribuição nas fibras musculares afetadas. O objetivo principal é o de avaliar uma possível correlação com o padrão de degeneração ou regeneração do músculo distrófico.

Alem disso, a análise da expressão da miostatina também está sendo realizada neste modelo animal, avaliando mais de 15 músculos diferentes de um mesmo cão adulto (Dinorah Zilberztajn, projeto para TCC, 2006).

\subsection{Estudo do potencial miogênico das células tronco mesenquimais $e$ embrionárias em modelos murinos para diferentes formas de distrofias musculares}


A identificação e caracterização de modelos animais com deficiências musculares semelhantes às descritas nas doenças humanas constituem importante ferramenta para a avaliação fisiopatológica do respectivo defeito molecular primário. Além disso, podem ter um papel significativo como modelo bioquímico e clínico para ensaios terapêuticos. Neste sentido, estudos em andamento visam testar o potencial de diversas células-tronco adultas e embrionárias de se diferenciar nas células do tecido afetado, e produzir a proteína nele deficiente.

A terapia celular em doenças genéticas visa à reposição de proteínas defeituosas ou ausentes através da inserção de genes normais presentes em células heterólogas que são introduzidas no tecido alterado. Estas carregam o gene não mutado até as células-alvo do organismo possuidor da mutação, ou como repositoras das fibras musculares perdidas por fibras normais. O procedimento consiste na injeção local ou por via sistêmica, de um grande número de células com potencial miogênico que deverão se direcionar aos músculos danificados onde irão se fundir entre si ou com as fibras danificadas (Karpati, 2002). É possível injetar mioblastos ou então células-tronco de diferentes origens.

As células-tronco são definidas por duas propriedades. Primeiro, elas são células que podem se dividir indefinidamente, produzindo populações idênticas à anterior. Além disso, elas também podem sofrer divisão assimétrica e dar origem a duas linhagens de células, uma idêntica à parental e outra que contém diferentes instruções genéticas e que se caracterizam por uma reduzida capacidade proliferativa e um potencial de desenvolvimento menor que o da célula original. Normalmente, as células-tronco são conhecidas como células progenitoras ou precursoras, comprometidas com a produção de uma ou poucas células diferenciadas (Fischbach, 2004).

Células-tronco embrionárias manipuladas em laboratórios são derivadas do grupo de células internas do blastocisto e são consideradas pluripotentes pois são capazes de se diferenciarem em qualquer tecido in vivo e in vitro. Por outro lado, células-tronco também são encontradas em tecidos adultos. Estas são células indiferenciadas intrínsecas a vários tecidos diferenciados do corpo são capazes de manter, gerar e repor células diferenciadas, apesar de não haver evidências de que elas são pluripotentes. Essas células podem ser encontradas em vários tecidos incluindo medula óssea, sistema nervoso central, epitélio, músculo cardíaco e músculo esquelético.

Dentre as células-tronco adultas, as células hematopoiéticas são as que estão melhor caracterizadas. Alem disso, atualmente, é sabido que células mesenquimais aderentes e multipotentes derivadas do estroma da medula óssea, de origem "adulta", dão origem a outros tecidos não hematopoiéticos, como osso, cartilagem e tecido conectivo in vivo (Pereira, 1995; Prockop, 1997) e in vitro (Deans, 2000; Minguell, 2000; Pittenger, 1999) e que podem ser fonte relevante de células com potencial de formar músculos in vitro (Wakitani, 1995). Entretanto, o recrutamento de células mesenquimais no processo miogênico ainda não foi comprovadamente observado in vivo (Ferrari, 1998). Por este potencial, várias tentativas estão sendo feitas no sentido de implantar células capazes de restabelecer a função das estruturas que estão prejudicadas nos pacientes. Devido a sua grande capacidade de auto-renovar, a sua plasticidade, a sua habilidade de circular na corrente sanguínea e uma maior facilidade de isolamento e cultura, as células mesenquimais aparecem como uma ferramenta atraente no contexto da engenharia genética e da terapia celular, apesar de pouco se conhecer a respeito dos mecanismos moleculares que governam seu potencial de célula-tronco.

Como se pôde comprovar, a cultura de células-tronco tem implicação na análise dos mecanismos das doenças, assim como ajuda no desenvolvimento de novas drogas e terapias alternativas. Para isso, torna-se imprescindível determinar a linhagem de células tronco mais viável capaz de promover a reparação ou a 
substituição perfeita do tecido em estudo.

Neste sentido, o desenvolvimento de ferramentas moleculares possibilitou a geração de animais transgênicos que expressam a proteína GFP, naturalmente presente em um tipo de água viva marinha. Desta forma todas as células (somáticas e tronco-embrionárias) geradas a partir destes animais expressam esta proteína, e podem ser identificadas por sua fluorescência verde. Esta é uma ferramenta poderosa no rastreamento destas células, quando injetadas em animais com doenças genéticas diversas.

Com base nestes dados, será testado o possível potencial miogênico de células tronco mesenquimais e embrionárias na reparação do processo de degeneração muscular em diferentes modelos com deficiências de proteínas musculares diversas. Os experimentos serão realizados in vivo e in vitro, através da detecção das proteínas primariamente deficientes em camundongos distróficos injetados com células-tronco normais e em experimentos de co-cultura. Será também avaliado o potencial de degeneração/regeneração nestes modelos terapêuticos. Os estudos no camundongo $m d x$, com deficiência de distrofina constituem projeto de mestrado de Danielle Ayub, e os estudos no camundongo SJL e LARGE constituem projeto de mestrado de Paula Onofre.

* Vainzof M, Yamamoto LU, Kossugue PM, Fogaça LLQ, Velloso FZ, Ayub D, Muniz VP, Zatz M, Silva, HCA, Massironi SMG, Miglino MA, Ambrosio CE, Miyazato LG, Moraes JRE, D’Angeles, FHF, Lacerda Neto JC, Mortari AC, Borges AS, Rezende LAL, Rahal SC. Modelos Animais ajudando a decifrar doenças neuromusculares humanas. V simposio de Hipertermia Maligna, Sao Paulo, 7-8 de outubro de 2005. Neurociencias, , 3 (13): 19-21, 2005.

* Vainzof M, Dani SU, Bogan J, Zatz M. Muscle Protein analysis in the canine Golden Retriever muscular dystrophy model (GRMD). 6th WORLD MUSCLE SOCIETY MEETING, Snowbird, Utah, USA, sept 6-8, Neuromusc. Disord. 11: 640-641, 2001.

Luciana Luchesi Quintanilha Fogaça - Projeto intitulado: estudo da expressão da proteína utrofina na distrofia canina . Programa de Biologia-Genética, Depto. De Biologia, Instituto de Biociências USP. Início: janeiro/2004.FAPESP.

Dinorah Zilberztajn. TCC - Ciências Biológicas. Projeto: estudo da expressão da miostatina em diferentes músculos do cão distrofico GRMD. Inicio: junho 2005. FAPESP.

Danielle Ayub de Barros Guerrieri Pinheiro. Projeto mestrado “Estudo do potencial miogênico das células tronco mesenquimais e embrionárias no modelo murino da distrofia muscular de Duchenne" Programa de BiologiaGenética, Depto. De Biologia, Instituto de Biociências USP. Início: janeiro/2005. FAPESP

Paula Cristina Gogueira Onofre. Projeto mestrado: Estudo do padrão de degeneração regeneração em modelos murinos distróficos. Programa de Biologia-Genética, Depto. de Genética de Biologia Evolutiva, Instituto de Biociências USP. Inicio: janeiro/2006. 


\section{RESUMO}

As afeç̧ões neuromusculares humanas constituem um grupo heterogêneo de doenças genéticas caracterizadas por degeneração muscular progressiva, levando ao desenvolvimento de fraqueza muscular e perda de capacidade motora. Mutações em vários genes resultam na deficiência ou perda de função de diversas proteínas musculares de importância significativa para o bom funcionamento do músculo. Estudos bioquímicos e imunohistológicos têm localizado estas proteínas na membrana sarcolemal (distrofina, $\alpha-, \beta-, \gamma-$ e $\delta$-sarcoglicanas, disferlina e caveolina 3 ), na matriz extracelular ( $\alpha 2$-laminina e colágeno $\mathrm{VI}$ ), nos sarcômeros (teletonina, miotilina, titina, actina e tropomiosina), no citosol muscular (calpaína 3, FRPR, TRIM32, miotubularina) e nos núcleos (emerina, lamina $A / C$, proteína $S M N$ ). Algumas doenças estão associadas a alterações nestas proteínas, dentre elas, as distrofias musculares progressivas e as miopatias congênitas. A deficiência da proteína distrofina é o defeito primário das formas de distrofias de Duchenne (DMD). Localizada no citoesqueleto de músculos esqueléticos e cardíacos, a distrofina se liga pelo domínio $\mathrm{N}$-terminal aos filamentos de actina e pelo domínio C-terminal ao complexo distrofina-glicoproteínas associadas, que por sua vez se ligam à lamina 2, na lamina basal. Desta forma, a distrofina promove a ligação entre as proteínas contráteis do músculo e a matriz extracelular, estabilizando e protegendo a membrana da fibra muscular contra o 'stress' mecânico ocasionado pela contração muscular. A fraqueza muscular apresentada pelos pacientes resulta do desequilíbrio entre os diversos ciclos de degeneração e regeneração sofridos pelo músculo.

Estudos clínicos e neurológicos em animais com fraqueza muscular têm ajudado a identificar alguns modelos animais tais como camundongos, cães e gatos, deficientes para diferentes proteínas musculares. Diversos modelos naturais para distrofias musculares humanas já são conhecidos. Dentre os modelos murinos, o camundongo $\mathrm{mdx}$ apresenta deficiência total da proteína distrofina no músculo, o camundongo dy/dy apresenta deficiência da proteína $\alpha 2$-laminina, e o modelo sjl apresenta deficiência de disferlina. Todos constituem excelentes modelos para a avaliação de novas estratégias com potencial terapêutico. Recentes têm-se ampliado o uso de camundongos transgênicos que expressam proteínas marcadoras, tais como a proteína fluorescente verde GFP. Estes animais constituem importantes ferramentas para o rastreamento destas células nos organismos receptores. Os estudos realizados nestes animais são cruciais para expandir nossos conhecimentos a respeito de doenças genéticas humanas, alem de terem um papel significativo como modelos moleculares, bioquímicos e clínicos para ensaios terapêuticos. 


\section{ABSTRACT}

Neuromuscular disorders are a heterogeneous group of genetic diseases, causing a progressive loss of the motor ability.

In the last decade, mutations in several gene have been identified, resulting in the deficiency or loss of function of different important proteins. In the muscular dystrophies group, the allelic X-linked Duchenne and Becker forms are caused by mutations in the dystrophin gene. Among the Limb-girdle forms, six autosomal dominant (LGMD 1A to LGMD1F) and ten autosomal recessive (LGMD2A-2J) are already known. The genes for the LGMD1 types were mapped respectively at 5q22-q34 (myotilin); 1q11-21 (lamin A/C), 3p25 (caveolin3), $6 q 23,5 q 31$ and 7q. Among the LGMD2 forms the 4 clinically more severe types, the sarcoglycanopathies (LGMD2C-2E, SGpathies), mapped at 17q21, 4q12, 13q12 and 5q33, encode respectively for $\alpha$-sarcoglycan $(\alpha-S G), \beta-S G, \gamma-S G$ and $\delta$-SG, that are glycoproteins of the sarcoglycan sub-complex of the dystrophinglycoprotein complex (DGC). The other 6 adult forms are LGMD2A at 15q (calpain 3), LGMD2B, at 2p31 (dysferlin), LGMD2G, at 17q11-12 (telethonin), LGMD 2H at 9q31-33 (TRIM32), LGMD2I at 19q13.3 (FukutinRelated Protein -FKRP), and LGMD2I at 2q24 (titin). Additionally, some congenital forms are also recognized, being the CMD1A with $\alpha 2$-laminin deficiency (at 6q2) the most common accounting for about $50 \%$ of the cases. Complementary biochemical and imunohistological analyses have localized these proteins in several compartments of the muscle fiber: in the sarcolemmal muscle membrane (dystrophin, sarcoglycans, dysferlin, caveolin 3), extracellular matrix ( $\alpha 2$-laminin, collagen $\mathrm{VI}$ ), in the sarcomere (telethonin, myotilin, titin), in the muscle cytosol (calpain 3, FRPR, TRIM32), and in the nucleus (emerin, lamin A/C, SMN protein).

Protein analysis can be used for the differential diagnosis and to direct the search for gene mutations, mainly because, in addition to genetic heterogeneity, most of the known genes are very large and presenting a wide variability of pathogenic mutations. Protein analysis is also of utmost importance for the elucidation of the physiopathology of each genetic disorder involved. Genotype-phenotype correlation through the analysis of the effect of different mutations on protein expression and on phenotypic variability contributes to the understanding of gene function.

Clinical and neurological studies in animals with muscular weakness have identified some models mainly for deficiencies of dystrophin, and proteins from the dystrophin-glycoprotein complex. The identification and characterization of animal models for protein deficiencies similar to human diseases will provide us with important tools for the elucidation of the physiopathological mechanism of the disease, aiming therapeutic trials 


\section{Bibliografia}

Akiyama C \& Nonaka I. A follow-up study of congenital non-progressive myopathies. Brain Dev. 1966, 18:404408.

Allamand V, Sunada Y, Salih MAM, et al. Mild congenital muscular dystrophy in two patients with na internally deleted laminin a2-chain. Hum. Mol. Genet. 1997, 6:747-752.

Anderson LV, Harrison RM, Pogue R et al. (2000). Secondary reduction in calpain 3 expression in patients with limb girdle muscular dystrophy type 2B and Miyoshi myopathy (primary dysferlinopathies). Neuromuscular Disorders, 10: 553-559.

Anderson LV, Davison K, Moss JA et al. (1999). Dysferlin is a plasma membrane protein and is expressed early in human development. Human Molecular Genetics, 8: 855-861.

Bitoun M, Maugenre S, Jeannet PY, Lacene E, Ferrer X, Laforet P, Martin JJ, Laporte J, Lochmuller H, Beggs $\mathrm{AH}$, Fardeau M, Eymard B, Romero NB, Guicheney P. Mutations in dynamin 2 cause dominant centronuclear

Nat Genet. 2005 Nov;37(11):1207-9., 2005

Bonnemann CG, Passos-Bueno MR, McNally EM, Vainzof M, Moreira ES, Marie SK, Pavanello RCM, Noguchi S, Ozawa E, Zatz M. Kunkel LM. Genomic screening for $\beta$-sarcoglycan mutations: Missense mutations may cause severe limb-girdle muscular dystrophy type 2E (LGMD 2E). Hum Mol Genet 5 (12): 1953-1961, 1996.

Brandt A, Schieithoff L, Jurkat-Rott K, Klingler W, Baur C, Lehmann-Horn L. Screening of the ryanodine receptor gene in 105 malignant hyperthermia families: novel mutations and concordance with the in vitro contacture test. Hum. Mol. Genet. 1999, 8: 2055-2062.

Charchat S, Gurgel-Giannetti J, Starling A, Zatz M, Vainzof M. Estudo da frequencia da nova mutação A150C no gene TPM3, em miopatia nemalínica e na população brasileira. . SIINCUSP, Ribeirão Preto, 7-8 de novembro de 2001.

Costa CS, Zatz M, Vainzof M. Estudo da Expressao do gene GDF8 em diferentes músculos de camundongos de linhagem distrófica (mdx). 47o Congresso Nacional de Genética, Águas de Lindoia, SP, 2-5 de outubro de 2001. Genet. Mol. Biol. 24, 2001.

Costa CS, Campos DA, Zatz M, Vainzof M. GDF8 expression and the degeneration/regeneration process in the mdx mice. 7th International Congress of the World Muscle Society Rotterdam, The Netherlands, 2-5 October, 2002. Neuromuscl. Disord. 12: 766, 2002

Cormand B, Avela K, Pinko $\mathrm{H}$ et al. Assignment of the muscle-eye-brain disease gene to $1 \mathrm{p} 32-34$ by linkage analysis and homozygosity mapping. Am.J.Hum.Genet. 1999, 64:126-135.

de Paula f, Vainzof M, Passos-Bueno MR, Pavanello RCM, Matioli SR, Anderson LVB, Nigro V, Zatz M. Clinical variability in calpainopathy: what makes the difference? Eur J. Hum. Genet. 10 (2): 825-32, 2002

Deans R. J., Moseley , A. B. Mesenchymal stem cells: Biology and potential clinical uses. Exper Hemat, 28: 875-884. 2002.

Dubowitz V. Workshop report: 68th ENMC-International workshop on congenital muscular dystrophy. 9-11 april 1999, Naarden, the Netherlands. Neuromusc. Disord. 1999: 9: 446-454.

Dubowitz, V. Muscle biopsy: A practical approach. 2a ed. London: Bailliere Tindall, 1985.

Ervasti JM, Campbell kP - A role for the dystrophin-glycoprotein complex as a transmembrane linker between laminin and actin. J. Cell Biol. 1993, 122: 809-823, 1993

Ferrari G., Stornaiuolo A., Mavilio , F. Bone marrow transplantation: Failure to correct murine muscular dystrophy. Nature, 411: 1014-1015, 2001

Fischbach G. D., Fischbach R. L. Stem cells: science, policy and ethics. J Clin Invest, 114: 1364-1370, 2004

Fukuyama, Y., H. Haruna, M. Kawazura: A peculiar form of congenital progressive muscular dystrophy. Report of 15 cases. Pediatr Univ (Tokyo) 1960, 4: 5-8.

Goebel HH, Fidzianska A. Classification of congenital myopathies. In: Lane, RJM: Handbook of Muscle Disease. $1^{\mathrm{a}}$ ed. New York: Marcel Dekker Inc., 1996. pp 165-176.

Gouveia TL, Paim JFO, Pavanello RCM, Zatz M, Vainzof M. . Sarcoglycanopathies: A multiplex analysis for the most common mutations. Diag. Mol. Pathol. In press, 2006

Gouveia TLF, Paim JFO, Zatz M, Vainzof M. "In vivo" evidences for the sarcoglycan complex organization in the sarcolemma in spite of the primary absence of $\delta$-SG. Submitted, 2006.

Guicheney P, Vignier N, Zhang X. PCR based mutation screening of the laminin 2-chain (LAMA2): application to prenatal diagnosis and search for founder effects in congenital muscular dystrophy. J. Med. Genet. 1998, 35:211-217.

Gurgel-Gianetti J, Umbertina Reed, Sueli K. Marie, Mary Carvalho, Edmar Zanoteli, Moacir A.T. Fireman, 
Acary S.B. Oliveira, Mayana Zatz, Mariz Vainzof. Nebulin Expression in patients with Nemaline Myopathy. Neuromusc. Disord. 11(2):154-62, 2001.

Gurgel-Giannetti J, Canovas M, Marie-Louise Bang, Umbertina Reed, Suely K Marie, Mayana Zatz, Siegfried Labeit, Mariz Vainzof. The lack of the C-terminal domain of nebulin in a patients with nemaline myopathy. Muscle\&Nerve 25: 747-52, 2002.

Gurgel-Giannetti J, Reed U, Zanoteli E, Werneck LC, Beggs A, Fireman MAT, Oliveira ACB, Zatz M, Vainzof M. Rod distribution and muscle fibers type modification in the progression of nemaline myopathy . J. child neurol, 18 (3): 235-40, 2003.

Hayashi YK, Chou F, Engvall E et al. Mutations in the integrin alpha 7 gene cause congenital myopathy. Nature Genet. 1998, 19:94-97.

Hayashi YK, Ishihara T, Domem K et al. A benign allelic form of laminin a2 chain deficient muscular dystrophy. Lancet 1997, 349: 1147.

Khurana TS, Davies KE. Pharmacological strategies for muscular dystrophy. Nat Rev Drug Discov. 2003 May;2(5):379-90. Review.

Kobayashi K, Nakahori Y, Miyake $\mathrm{M}$ et al. $\mathrm{Na}$ ancient retrotransposal insertion causes Fukuyama-type congenital muscular dystrophy. Nature 1998, 394:388-392.

Koenig M., Beggs A. H., Moyer M., e col. SCHERPF, S. The molecular basis for Duchenne versus Becker muscular dystrophy: correlation of severity with type of deletion. Am J Hum Genet, 45: 498-506, 1989.

Kossugue PM, Paim JFO, Silva HC, Pavanello RCM, Gurgel Giannetti J,Zatz M, Vainzof M, Central Core disease due to recessive mutations in RYR1 gene: is it more common than described? Muscle and Nerve (em revisão), 2006

Laport J, Guiraud-Chaumeil C, Vincent M-C, et al. Mutations in the MTM1 gene implicated in X-linked myotubular myopathy. Hum. Mol. Genet. 1997, 6:1505-1511.

Laporte J, Hu lj, Kretz C, Mandel JL (group 1), Kioschis P, Coy JF, Klauck SM, Poustka A (group 2), Dahl N (group 3). A gene mutated in X-linked myotubular myopathy defines a new putative tyrosine phosphatase family conserved in yeast. Nat. Genet. 1996, 13:175-182.

Lima BL, Gouveia TL, Zatz M, Pavanello RCM, Vainzof M. Estudo molecular do gene da teletonina em pacientes com distrofias musculares das cinturas. 12o Simpósio Internacional de Iniciação científica da Universidade de São Paulo. Ribeirão Preto, 23-24 de novembro de 2004-11-05

Lima BL, Gouveia TL, Pavanello RC, Faulkner G, Valle G, Zatz M, Vainzof M. LGMD2G: screening for mutations in a large sample of Brazilian patients allows the identification of new cases. 10th International Congress of the World Muscle Society, Iguassu Falls, Brazil, September 28 to October 1, 2005. Neurom Disord 15: 687, 2005

Lima HP, Gouveia TLF, Zatz M, Vainzof M. Triagem de mutações no gene MTM na miopatia miotubular. 48o Congresso Brasileiro de Genética, Águas de Lindóia, 17-20 de setembro de 2002.

Lima HP, Gouveia TLF, Tsanaclis AMC, Gurgel-Gianneti J, Silva HCA, Zatz M, Laporte J, Vainzof M. Myotubularin protein and DNA analysise in myotubular myopathy. 8th International Congress of the World Muscle Society, Szeged, September 3-6, 2003. Neuromuscl. Disord. 13: 628, 2003.

Lima BL, Gurgel-Gianneti J; Zanoteli E, Vainzof M. Estudo de mutações no gene alfa actina em pacientes com miopatia nemalínica. 49o Congresso Nacional de Genética. Águas de Lindóia, SP, 16-19 de setembro de 2003.

Mahjneh I, Passo-Bueno MR, Zatz M, Vainzof M, Marconi G, Nashef L, Bashir R, Bushby K. The phenotype of chromosome 2p-linked limb-girdle muscular dystrophy. Neurom. Disord. 6: 483-490, 1996.

McNallly E, Passos-Bueno MR, Bonnemann C, Vainzof M, Moreira ES, Lidov H, Ben Othmane K, Denton P, Vance J, Zatz M, Kunkel LM. Mild and Severe muscular dystrophy caused by a single $\gamma$-Sarcoglycan mutation. Am J Hum Genet, 59: 1040-1047, 1996.

Minetti C, Sotgia F, Bruno $\mathrm{C}$ et al. Mutations in the caveolin-3 gene cause autosomal dominant limb-girdle muscular dystrophy. Nature Genetics, 18: 365-368.

Minguell J. J., Conget P., Erices A. (2000). Biology and clinical utilization of mesenchymal progenitor cells. Braz J Med Biol Res, 33: 881-887, 2000.

Moreira ES, Vainzof M, Marie SK, Nigro V, Zatz M, Passos-Bueno MR. A first missense mutation in the $\partial-$ sarcoglycan gene associated with a severe phonotype and frequency of limb-girdle muscular dystrophy type 2F (LGMD2F) among Brazilian sarcoglycanopathies. J. Med. Genet. 35:951-953, 1998.

Moreira ES, Vainzof M, Suzuki OT, Pavanello RC, Zatz M, Passos-Bueno MR.Genotype-phenotype correlations in 35 Brazilian families with sarcoglycanopathies including the description of three novel 
mutations. J Med Genet. 40(2):E12. 2003

Moreira ES, Vainzof M, Marie SK, Sertie AL, Zatz M, Passos-Bueno MR. The seventh form of autosomal recessive limb-girdle muscular dystrophy is mapped to 17q11-12. Am. J.Hum.Genet. 61: 151-159, 1997.

Moreira ES, Wiltshire TJ, Faulkner G, Nilforoushan A, Vainzof M, Suzuki OT, Valle G, Reeves R, Zatz M, Passos-Bueno MR, Jenne D. Limb-girdle muscular dystrophy type 2G (LGMD2G) is caused by mutations in the gene encoding the sarcomeric protein telethonin. Nature Genet. 24:163-166, 2000.

Muniz VP, Silva HC, Pavanello RCM, Cerqueira A, Zatz M, Vainzof M. Molecular analysis of the myostatin gene in patients with muscle hypertrophy due to genetic congenital myotonia. Neuropediatrics, submetido, 2006

Muniz VP, Silva HCM, Zatz M, Vainzof M. Study of the myostatin gene (GDF8) in patients with muscle hypertrophy due to genetic congenital myotonia. 10th International Congress of the World Muscle Society, Iguassu Falls, Brazil, September 28 to October 1, 2005. Neurom Disord 15: 687, 2005

Muniz VP, Oliveira ASB, M. Vainzof M. Muscular fiber type differentiation and polymorphisms in the myostatin gene (GDF8). 10th International Congress of the World Muscle Society, Iguassu Falls, Brazil, September 28 to October 1, 2005. Neurom Disord 15: 687, 2005.

Muniz VP, Silva HCA, Tsanaclis AMC, Vainzof M. Screening for mutations in the RYR1 gene in families with malignant hyperthermia. J. Molec. Neurosc. 21(1):35-42. 2003.

Nigro V, Moreira, ES, Piluso G, Vainzof M, Belsito A, Politano L, Puca AA, Passos-Bueno MR, Zatz M. The $5 q$ autosomal recessive limb-girdle muscular dystrophy (LGMD2F) is caused by a mutation in the $\delta$ sarcoglycan gene. Nature Genetics 14: 195-198, 1996

North KN, Laing NG, Wallgreen-Pettersson CJ. Nemaline myopathy: currents concepts. Med. Genet. 1997, 34:705-713.

North KN, Yang N, Wattanasirichaigoon D, Mills M, Easteal S, Beggs A. A common nonsense mutation results in -actinin3 deficiency in the general population. Nature Genet. 1999, 21:353-354.

Pallavicini A, Koji S, Bean c, Vainzof M, slamon M, levolella C, Bortoletto G, Pacchioni B, Zatz M, Lnafranchi G, Faulkner G, Valle G. Characterization of human skeletal Ankrd2. Biochem Biophys Res Commun 2001 Jul 13;285(2):378-86

Passos-Bueno MR, Vainzof M, Marie SK, Zatz M. Half the dystrophin gene is apparently enough for a mild clinical course: confirmation of its potential use for gene therapy. Hum Mol Genet 3:919-922, 1994

Passos-Bueno, M.R.; Oliveira, J.R.; Bakker, E.; Anderson, R.D.; Marie, S.K.; Vainzof, M.; Roberds, S; Campbell, K.P.; Zatz, M. Genetic heterogeneity for Duchenne-like muscular dystrophy (DLMD) based on linkage and 50 DAG analysis. Hum. Mol. Genet. 2: 1945-1947, 1993c.

Passos-Bueno MR, Moreira ES, Vainzof M, Chamberlain J, Marie SK, Pereira LV, Akiyama J, Roberds SL, Campbell KP, Zatz M. A common missense mutation in the adhalin gene in three unrelated Brazilian families with a relatively mild form of autosomal recesiv limb girdle muscular dystrophy. Hum. Mol. Genet. 4 (7): 1163-1167, 1995.

Passos-Bueno MR, Moreira ES, Vainzof M, Marie SK, Zatz M. Linkage analysis in autosomal recessive limbgirdle muscular dystrophy maps a sixth form to 5q33-34 (LGMD2F) and indicates that there is at least one more subtype of AR LGMD. Hum Mol Genet 5: 815-820, 1996.

Passos-Bueno MR, Vainzof M, Moreira ES, Zatz M. Seven autosomal rcessive limb-girdle muscular dystrophies in the brazilian population: From LGMD2A to LGMD2G. Am.J.Med.Genet. 82:392-398, 1999

Passos-Bueno, M.R., Terwilliger, J., Ott, J., Love, D., Vainzof, M., Davies, K.E., Zatz, M. (1990): Linkage analysis in families with autosomal recessive Limb-girdle muscular dystrophy and $6 q$ probes flanking the dystrophin-related sequnce. Am. J. Med. Genet., 38: 140-

Passos-Bueno, M.R., Vainzof, M., Pavanello, R.C.M., Pavanello-Filho, I., Lima, M.A.B.O., Zatz M: Limb-girdle syndrome: a genetic study of 22 large Brazilian families: comparison with X-linked Duchenne and Becker dystrophies. J. Neurol. Sci. 103:65-75, 1991.

Passos-Bueno, M.R.; Richard, I.; Vainzof, M.; Fougerouse, F.; Weissenbach, J.; Broux, D.; Cohen, D.; Guilherme, L.; Kalil, J.; Zatz, M.; Backmann, J.S. - Evidence of genetic heterogeneity for the autosomal recessive adult forms of limb-girdle muscular dystrophy following linkage analysis with $15 q$ probes in Brazilian families. J. Med. Genet.30: 385-387, 1993a.

Passos-Bueno, M.R.; Beckmann, J.; Vainzof, M.; Pavanello, R.C.M.; Marie, S.K.; Zatz, M. - Exclusion of the $15 q$ locus as a candidate gene for severe childhood autosomal recessive Duchenne-like muscular dystrophy in Brazilian families. Hum. Mol. Genet. 2:201-202, $1993 \mathrm{~b}$.

Passos-Bueno MR, Bashir R, Moreira ES, Vainzof M, Marie SK, Vasquez L, lughetti P, Bakker E, Keers S, Stephenson A, Strachan T, Mahneh I, Weissenbach J, Bushby K, Zatz M. Confirmation of the $2 p$ locus for mild autosomal recessive limb-girdle muscular dystrophy in three families allows refinement of the 
candidate region. Genomic , 27: 192-195, 1995

Passos-Bueno MR, Moreira ES, Marie SK, Bashir R, Vasquez L, Love DR, Vainzof M, iughetti P, Oliveira JR, Bakker E, Strachan T, Bushby K, Zatz M. Main clinical features for the three mapped autosomal recessive limb girdle muscular dystrophies and estimated proportion of each form in 13 brazilian families. J. Med. Genet. 33:97-102, 1996.

Pereira R. F., Halford K. W., O`Hara e col. Cultured adherent cells from marrow can serve as long-lasting precursor cells for bone, cartilage, and lung in irradiated mice. Proc Natl Acad Sci USA, 92: 4857-4861, 1995.

Pittenger M., Mackay A. M., Beck S. C. e col. Multilineage potential of adult human mesenchymal stem cells. Science, 284: 143-147, 1999.

Prockop D. J. Marrow stromal cells as stem cells for nonhematopoietic tissues. Science, 276: 71-74, 1997

Spencer MJ, Tidball JG, Anderson LVB, Bushby KMD, Harris JB, Passos-Bueno MR, Somer H, Vainzof M, Zatz M. Absence of calpain 3 in a form of limb-girdle muscular dystrophy (LGMD2A). J. Neurol. Sci., 146: 173-178, 1997

Starling A, Paula F, Silva H, Vainzof M, Zatz M. Calpainopathy: how broad is the spectrum of clinical variability? J Mol Neurosc 21:233-236, 2003

Starling A, Schlesinger D, Kok F, Passos-Bueno MR, Vainzof M, Zatz M. A family with McLeod syndrome and calpainopathy with clinically overlapping diseases. Neurology 13;65(11):1832-3. 2005.

Tanner SM, Schneider V, Thomas NST, Clarke A, Lazarou, L, Liechti-Gallati S. Characterization of 34 novel and six known MTM1 gene mutations in 47 unrelated X-linked myotubular myopathy patients. Neuromusc. Disord. 1999, 9:41-49.

Toda T, Segawa M, Nomura $\mathrm{Y}$, et al. Localization of a gene for Fukuyama type congenital muscular dystrophy to chromosome 19q31-33. Nature Genet. 1993, 5:283-286

Tomé FMS, Evangelista T, Leclerc A, Sunada Y, Manole E, Estournet B, Barois A, Campbell KP, Fardeau M. Congenital muscular dystrophy with merosin deficiency. C.R. Acad. Sci Paris, Sciences de la vie/Life sciences 1994, 317: 351-357.

Tomé FMS, Guicheney P, Fardeau M. Congenital muscula dystrophy. In: Emery AEH (Ed). Neuromuscular Disorders: Clinical and Molecular Genetics. $1^{\text {a }}$ ed. New York: Johan Wiley \& Sons, 1998. pp 21-57.

Topaloglu H, Talim B, Vignier N, Helbling-Leclerc A, et al. Merosin-deficient congenital muscular dystrophy with severe mental retardation and normal cranial MRI: a report of two sibilings. Neuromusc. Disord. 1998, 8: $169-174$

Vainzof M, Zatz M. Protein defects in Neuromuscular disorders. Br J Med Biol Res 36(5): 543-555, 2003.

Vainzof M, Passos-Bueno MR, Zatz M. Immunological methods for the analysis of protein expression in neurmuscular diseases. In: Potter, NT: Methods in Molecular Medicine-Neurogenetics: Methods and Protocols. Humana Press Inc., Totowa, NJ, pp 355-378,2003.

Vainzof M, Yamamoto LU, Gouveia TLF, Zatz M. The contribution of protein analysis in the diagnosis of neuromuscular diseases. In: Burgess V.N. Trends in Muscular Dystrophy Research. Nova Publisher, USA.,2005

Vainzof M, Zatz M. Muscular dystrophies and protein mutations. (2006) in: Uversky VN and Fink AL., Protein Misfolding, Aggregation and Conformational Diseases.

Vainzof, M.; Pavanello, R.C.M.; Pavanello, I.; Passos-Bueno, M.R.; Rapaport, D.; Zatz, M. - Dystrophin immunostaining in muscles from patients with different types of muscular dystrophy: A brazilian study $\mathrm{J}$. Neurol. Sci. 98: 221-233, 1990.

Vainzof, M.; Zubrzycka-Gaarn, E.E.; Rapaport, D.; Passos-Bueno, M.R.; Pavanello, I.; Zatz, M. Immunofluorescence dystrophin study in Duchenne dystrophy through the concomitant use of two antibodies directed against the carboxi-terminal and the amino-terminal region of the protein. J. Neurol. Sci., 101 (2):141-147, 1991a.

Vainzof, M.; Pavanello, R.C.M.; Pavanello, I.; Passos-Bueno, M.R.; Rapaport, D.; Chu, T.C.; Levy, J.A.; Allegro, M.C.; Salum, P.N.; Zatz, M. - Estudo imunohistoquímico da Distrofina em músculo de afetados por distrofias musculares progressivas. Rev.Bras.Genet. 14:799-812, 1991b.

Vainzof, M.; Passos-Bueno, M.R.; Takata, R.I.; Pavanello, R.C.M.; Zatz, M. Intrafamilial variability in dystrophin abundance correlated with difference in the severity of the phenotype. J. Neurol. Sci.119: 38-42, 1993a

Vainzof, M.; Passos-Bueno, M.R.; Nguyen thi Man, Zatz, M. Absence of correlation between utrophin localization and quantity and the clinical severity in Duchenne Dystrophy (DMD). Am J Med Genet 58;305309, 1995. 
Vainzof, M.; Pavanello, R.C.M.; Pavanello, I.; Rapaport, D.; Passos- Bueno, M.R.; Zubrzycka-Gaarn, E.E.; Bulman, D.; Zatz, M. - Screening of male patients with autosomal recessive Duchenne dystrophy through dystrophin and DNA studies. Am. J. Med. Genet. 39:38-41, 1991

Vainzof, M.; Passos-Bueno, M.R.; Rapaport, D.; Pavanello, R.C.M.; Bulman, D.E,; Zatz, M. Additional dystrophin fragment in Becker muscular dystrphy patients: Correlation with the pattern of DNA deletions. Am. J. Med. Genet., 44:382-384, 1992.

Vainzof, M.; Passos-Bueno, M.R., Pavanello R.C.M., Zatz, M. Is dystrophin always altered in Becker muscular dystrophy patients? J Neurol. Sci. 131:99-104, 1995

Vainzof, M.; Pavanello, R.C.M.; Pavanello, I.; Tsanaclis, A.M.; Levy, J.A.; Passos-Bueno, M.R.; Rapaport, D.; Zatz, M. - Dystrophin immunofluorescence pattern in manifesting and asymptomatic carriers of Duchenne's and Becker muscular dystrophy of different ages. Neuromus. Disord., 1 (3): 177-183, 1991.

Vainzof, M.; Nicholson, L.V.B.; Bulman, D.E.; Tsanaclis, A.M.; Passos-Bueno, M.R.; Pavanello, R.C.M.; Zatz, M. - Sarcolemmal distribution of abnormal dystrophin in Xp21 carriers. Neuromusc. Disord. 3: 135-140, 1993.

Vainzof, M.; Passos-Bueno, M.R.; Pavanello, R.C.M.; Schreiber, R.; Zatz M. - A model to estimate the expression of the dystrophin gene in muscle from Becker female muscular dystrophy carriers. J. Med. Genet., 22:476-479, 1992

Vainzof M, Passos-Bueno MR, Moreira ES, Pavanello RCM, Marie SK, Andreson LVB, Bonnemann CG, McNally EM, Nigro V, Kunkel LM, Zatz M. The sarcoglycan complex in the six autosomal recessive limbgirdle (AR_LGMD) muscular dystrophies. Hum Mol Genet, 5 (12): 1963-1969, 1996.

Vainzof M, Passos-Bueno MR, Pavanello RCM, Marie SK, Zatz M. Sarcoglycanophathy is responsible for $68 \%$ of severe autosomal recessive limb-girdle muscular dystrophy. J. Neurol. Sci 164 (1): 44-49, 1999.

Vainzof M, Anderson LVB, Moreira ES, Passos-Bueno MR, Pavanello RCM, Zatz M. LGMD2A: muscle calpain analysis in Brazilian LGMD patients. 4th International Congress of the World Muscle Society. Antalya, Turquia, 14-16 outubro de 1999. Neurom.Disord. 9: 506, 1999.

Vainzof M, Anderson LVB, Moreira ES, Passos-Bueno MR, Pavanello RCM, Zatz M. Calpain 3: Characterization of the primary defect in LGMD2A and analysis of its secondary effect in other LGMDs. 52nd annual Meeting of the American Academy of Neurology. San Diego, CA, 29/4-6/5, 2000. Neurology 54: A436, 2000

Vainzof M, Moreira ES, Passos-Bueno MR et al. (2002). The effect of telethonin deficiency in LGMD-2G and its expression in other forms of muscular dystrophies and congenital myopathies. Biochimica et Biophysica Acta - Genetic Basis of Diseases, 1588: 33-40.

Vainzof M, de Paula F, Tsanaclis AM, Zatz M. The effect of calpain 3 deficiency in the pattern of muscle degeneration in the earliest stages of LGMD2A. J. Clinical Pathol, 56: 624-626, 2003.

Vainzof M, Pavanello RCM, Anderson LVB, Moreira ES, Passos-Bueno MR \& Zatz M (2001). Dysferlin analysis in autosomal recessive limb-girdle muscular dystrophies (AR-LGMD). Journal of Molecular Neuroscience, 17: 71-80.

Vainzof M, Anderson LVB, McNally EM, Davis DB, Faulkner G, Moreira ES, Pavanello RCM, Passos-Bueno MR, Zatz M. Dysferlin protein analysis in limb-girdle muscular dystrophies. J Mole. Neurosc. 17:71-80, 2001.

Vainzof M, E.S. Moreira, M.R. G. Faulkner, G. Valle, E., A. Beggs, O. Carpen, A.F. Ribeiro, E. Zanoteli, J. Gurgel-Gianneti, A.M. Tsanaclis, Helga C.A. Silva, M.R. Passos-Bueno, M. Zatz. Telethonin expression in Limb girdle muscular .BBA - Biochim Biophys Acta 1588(1):33-38,2002

Vainzof M, Anderson LVB, Moreira ES, Passos-Bueno MR, Pavanello RCM, Zatz M. Calpain 3: Characterization of the primary defect in LGMD2A and analysis of its secondary effect in other LGMDs. 52nd annual Meeting of the American Academy of Neurology. San Diego, CA, 29/4-6/5, 2000. Neurology 54: A436, 2000.

Vainzof M, Pavanello RCM, Anderson LVB, Moreira ES, Passos-Bueno MR \& Zatz M (2001). Dysferlin analysis in autosomal recessive limb-girdle muscular dystrophies (AR-LGMD). Journal of Molecular Neuroscience, 17: 71-80.

Vainzof M, Moreira ES, Passos-Bueno MR et al. (2002). The effect of telethonin deficiency in LGMD-2G and its expression in other forms of muscular dystrophies and congenital myopathies. Biochimica et Biophysica Acta - Genetic Basis of Diseases, 1588: 33-40.

Vainzof M, Moreira ES, Ferraz G, Passos-Bueno MR, Marie SK, Zatz M. Further evidences for the organization of the four sarcoglycans proteins within the dystrophin-glycoprotein complex. Eur. J. Hum Genet 7:251-254, 1999

Vainzof M, Moreira ES, Canovas M, Suzuki OT, Pavanello RCM, Costa CS, Passos-Bueno MR, Zatz M. 
Partial $\alpha$-sarcoglycan deficiency associated with the retention of the SG complex in a LGMD2D family. Muscle\&Nerve, 23: (6) 984-988, 2000.

Vainzof M, Canovas M, Labeit S, Bang ML, Faulkner G, Valle G, Zatz M. Sarcomeric myopalladin study in limb-girdle muscular dystrophies. Xth Internacional Congress on Neuromuscular Diseases, Vancouver, Canadá, 7-12 julho de 2002. J. Neurol. Sci199:S33, 2002.

Vainzof M, Kossugue PM, Yamamoto LU, Gouveia TLF, Santos BGC, Lima BL Gurgel-Giannetti J, Moza M, Carpen O. Heterogeneity in myotilin expression in a patient with Limb Girdle Muscular Dystrophy. 9th International Congress of the World Muscle Society, Goteborg, Sweden, September 1-4, 2004. Neuromusc. Disord.14:606, 2004

Velloso FJ, Yamamoto LU, Zatz M, Chimelli LMC, Kashiwagi F, , Vainzof M,. Study of the PTPLA gene in Centronuclear myopathy. 10th International Congress of the World Muscle Society, Iguassu Falls, Brazil, September 28 to October 1, 2005

Wakitani S., Saito T., Caplan A. I. Myogenic cells derived from rat bone marrow mesenchymal stem cells exposed to 5-azacytidine. Muscle Nerve, 18: 1417-1426, 1995.

Wallgren-Pettersson CA, Clarke A. Myotubular myopathy. In: Emery AEH (Ed). Neuromuscular Disorders: Clinical and Molecular Genetics. 1a ed. New York: Johan Wiley \& Sons, 1998. pp 262-276

Wallgren-Pettersson CA, Pelin K, Hipela $\mathrm{P}$, Donner $\mathrm{K}$ et al. Clinical and genetic heterogeneity in autosomal recessive nemaline myopathy. Neuromusc. Disord. 1999, 9:564-572.

C. Wallgren-Pettersson1*, MD, PhD, K. Pelin1**, PhD, K. J. Nowak2, PhD, F. Muntoni3 MD, PhD, N. B. Romero4 MD, PhD, H. H. Goebel5 MD, PhD, K.N. North6 MD, PhD, A. H. Beggs7, PhD, N.G. Laing2, PhD, and the ENMC International Consortium on Nemaline Myopathy. Genotype-phenotype correlations in nemaline myopathy caused by mutations in nebulin and $\alpha$-actin. Neurom. Disrod 14(8-9):461-70, 2004

Wedel DJ. Malignant hyperthermia and neuromuscular disease. Neuromusc.Disord. 1992, 2:157-164.

Yamamoto LU, Canovas M, B.L. Lima, F. de Paula, N. Vieira, M. Zatz, M. Vainzof. Muscle proteins alteration in patients with mutations in the Fukutin-Related Protein gene. 53rd annual meeting of the American Society of Human Genetics, Los Angeles, November 4-8, 2003. Am. J. Hum. Genet. 73:556, 2003.

Yamamoto LU, de Paula F, Pavanello RCM, Vieira N, Zatz M,Vainzof M. LGMD2I - secondary muscle protein alteration in patients with mutations in the Fukutin-Related Protein gene. 9th International Congress of the World Muscle Society, Goteborg, Sweden, September 1-4, 2004. Neuromusc. Disord., 14:579, 2004a.

Yamamoto, LU, Paula F, Vieira N, Pavanello RCM, Canovas M, Zatz M, Vainzof M. Alteracoes na expressao de proeinas musculares em pacientes com mutacoes no gene FKRP (Fukutin-related Protein). 40 Encontro da Sociedade Brasileira de Investigacao Neurológica, Curitiba, 18-19 de junho de 2004 . O Dendrito, 10 (2): 32, 2004b.

Zanoteli E, Renato M Lotuffo, Acary SB Oliveira, Alan H Beggs, Marta Canovas, Mayana Zatz, Mariz Vainzof. Deficiency of Muscle alpha-Actinin-3 is Compatible with High Muscle Performance J. Molec. Neurosc 20(1):39-42, .2003.

Zatz M, Starling AS, de Paulo F, Vainzof M. The ten autosomal recessive Limb-Girdle Muscular Dystrophies. Neurom. Disord. 13 (7-8):532-44, 2003.

Zatz, M.; Matsumura, K.; Vainzof, M.; Passos-Bueno, M.R.; Pavanello, R.C.M.; Marie, S.K.N.; Campbell, K.P. Assessment of the 50-kDa dystrophin-associated glycoproteins in Brazilian patients with severe childhood autosomal recessive muscular dystrophy. J. Neurol. Sci. 123:122-128, 1994. 